\title{
Evaluation of Energy-Conserving Modifications for Water Heaters
}

Robert I.. Palla, Jr.

Center for Consumer Product Technology National Engineering Laboratory

National Bureau of Standards

Washington, [..C. 20234

Suly 1979

Final

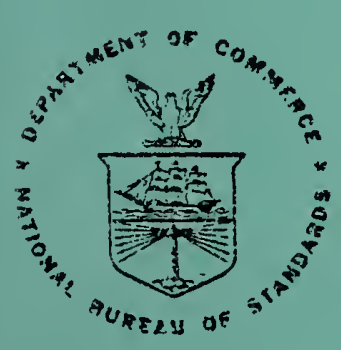

U.S. DEPARTMENT OF COMMERCE$$
-1
$$

100 .456

$79-1783$

1979 C. 2
NATIONAL BUREAU OF STANCA.TES 
2

NBSIR 79-1783

\section{EVALUATION OF ENERGY-CONSERVING MODIFICATIONS FOR WATER HEATERS}

Robert L. Palla, Jr.

Center for Consumer Product Technology National Engineering Laboratory National Bureau of Standards Washington, D.C. 20234

Juiy 1979

Final

U.S. DEPARTMENT OF COMMERCE, Juanita M. Kreps, Secretary Luther H. Hodges, Jr., Under Secretary Jordan J. Baruch. Assistant Secretary for Science and Technology NATIONAL BUREAU OF STANDARDS, Ernest Ambler, Director 
The effects of various energy-conserving modifications on water heating energy consumption were evaluated based on laboratory tests. Nine storage-type residential water heaters, representative of standard and "energy-saving" electric, gas, and oil fueled models currently on the market, were obtained for testing. Federally-promulgated water heater test procedures were used to measure the energy consumption of each unit before and after modifications. Energy-conserving modifications and corresponding projected reductions in energy consumption included: reduced thermostat settings $\left(10^{\circ} \mathrm{C}\right), 12$ percent savings for standard electric, gas, and oil fueled water heaters (where appliance performance does not degrade below an acceptable level, and water heater capacity is still sufficient to meet hot water needs); and improved insulation, 9 percent savings for all water heater fuel types. Also considered for gas-fired units were reduced pilot input rate from $220 \mathrm{~W}$ to $60 \mathrm{~W}(750 \mathrm{Btu} / \mathrm{h}$ to $200 \mathrm{Btu} / \mathrm{h})$, less than 2 percent savings; use of thermal dampers, 3 percent savings; use of intermittent ignition, 5 percent savings; and use of intermittent ignition and mechanical flue dampers, 11 to 16 percent savings. Modifications to energy-saving models resulted in somewhat smaller reductions. Multiple modifications were found to offer energy savings slightly less than the sum of the individual savings.

Key Words: Energy conservation; energy consumption; heat loss; insulation; modifications; gas pilot; recovery efficiency; residential; standby loss; test procedures; water heaters 
ABSTRACT

LIST OF TABLES

iv

LIST OF FIGURES

$\mathrm{v}$

NOMENCLATURE

vi

1. Introduction

2. Energy Conserving Modifications

2.1 Reduced Thermostat Settings

2.2 Insulation Improvements

2.3 Decreased Pilot Input Rates

2.4 Intermittent Ignition and Flue Dampers

2.5 Thermal Losses From Water Heater Fittings

3. Laboratory Facilities

4. Test Procedures

5. Test Results

5.1 Reduced Thermostat Settings

5.2 Insulation Improvements

5.2.1 Added Insulation

5.2.2 Added Insulation and Reduced Thermostat Settings

5.2.3 Decreased Thermal Conductivity of Insulation

5.2.4 Decreased Thermal Conductivity, Increased Thickness of Insulation

5.3 Decreased Pilot Input Rates

5.4 Intermittent Ignition and Flue Dampers 
5.4.2 Intermittent Ignition and Mechanical Flue Dampers for Gas-Fired Units

5.4.3 Thermal Flue Dampers for Gas-Fired Units

5.4.4 Mechanical Flue Dampers for Oil-Fired Units

5.5 Thermal Losses From Water Heater Fittings

6. Summary and Conclusions

7. References

Tables

Figures

Appendix A - Determination of Standby Loss from Cool-Down 35 and Recovery Tests

Appendix B - Effect of Thermostat Reduction on Water Heating Energy Requirements 


\section{LIST OF TABLES}

Table 1 Characteristics of Water Heaters Tested

Table 2 Summary of Potential Energy Savings

Table 3 Effect of Reducing Thermostat Settings

Table 4 Effect of Adding $33 \mathrm{~mm}$ of Extra Insulation

Table 5 Effect of Adding Extra Insulation and Reducing Thermostat Setting

Table 6 Replacement of Original Insulation With Improved Insulation

Table 7 Replacement of Original Insulation With Improved Insulation of Increased Thickness

Table 8 Standby Loss at Various Pilot Input Rates

Table 9 Replacement of Gas Pilot With Intermittent Ignition

Table 10 Replacement of Gas Pilot With Intermittent Ignition and Mechanical Flue Damper

Table 11 Use of a Thermal Damper With Gas-Fired Water Heaters

Table 12 Use of a Mechanical Flue Damper With an Oil-Fired Water Heater 
Figure 1 Schematic of a Typical Gas-Fired Water Heater

Figure 2 Temperature Profile of a Typical Water Heater Cycle During Standby

Figure 3 Recovery Efficiency Versus Water Temperature Rise Per Cycle For One Gas-Fired Water Heater Tested

Figure 4 Standby Loss as a Function of Gas Pilot Input Rate

Figure 5 Heat Loss Measurement Apparatus

Figure 6 System Power Input Versus Equilibrium Temperature Above Arnbient, With and Without Temperature-Pressure Relief Valve (TPRV) Installed 


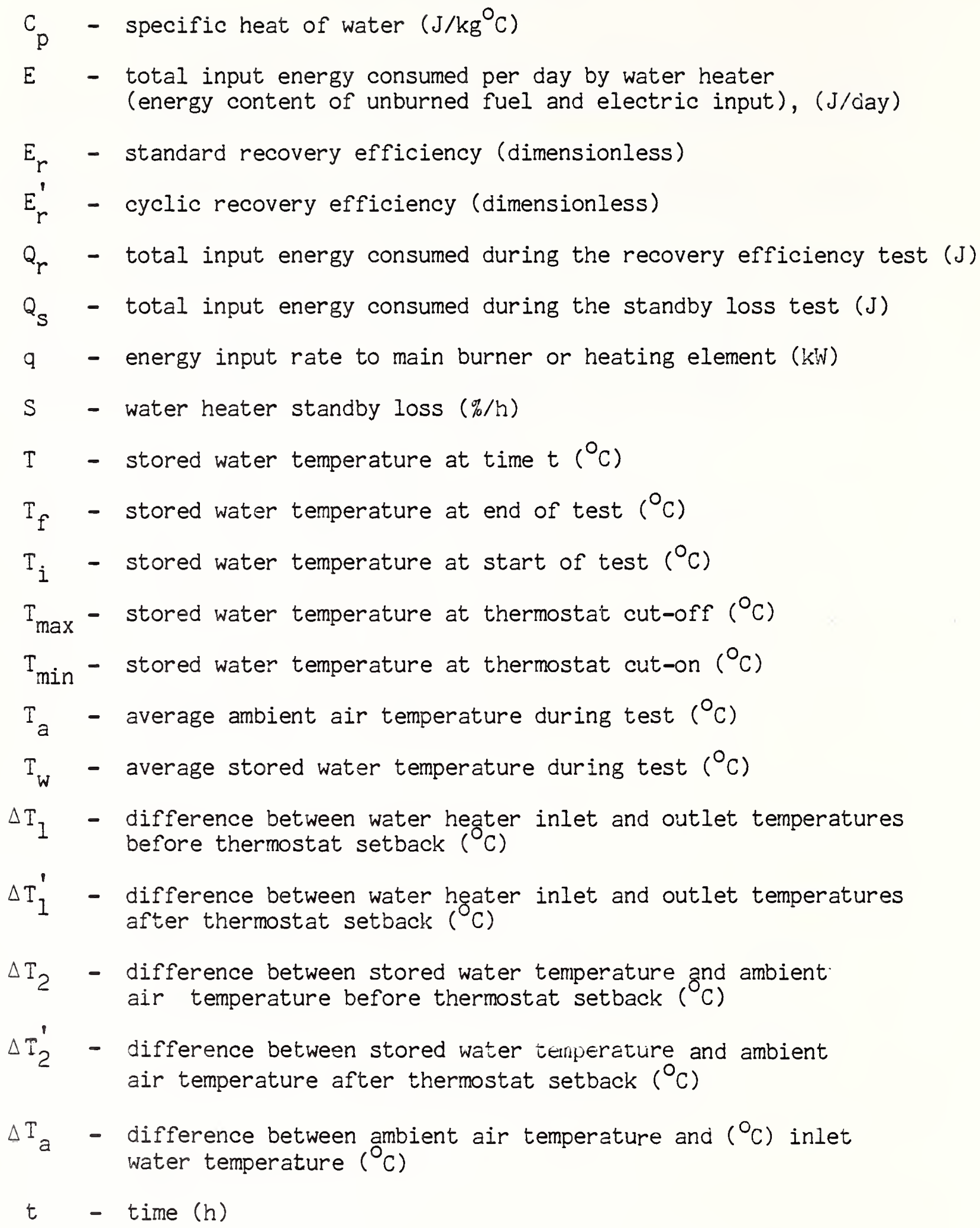


$t_{c}$ - duration of cool-down period in standby mode ( $h$ )

$t_{b}$ - duration of burner heating period in standby mode ( $h$ )

$U$ - daily hot water usage rate before thermostat setback (L/day)

$U^{\prime}$ - daily hot water usage rate after thermostat setback (L/day)

V - tank volume (L)

$\rho$ - density of water $(\mathrm{kg} / \mathrm{L})$

$\tau$ - water heater cool-down time constant $(h)$

$\phi \quad$ - fraction of hot water going to clothes washer and dishwasher (dimensionless) 



\section{INTRODUCTION}

In the United States, domestic hot water is supplied almost exclusively by automatic, storage-type water heaters using electricity, gas, or fuel oil as an energy source. These storage-type water heaters perform two basic functions in supplying hot water: (1) they heat the incoming cold water, and (2) they store this heated water until it is delivered. Thermal losses occur in each of these processes and add substantially to the energy requirements for water heating.

Several investigators $[1,2]^{*}$ have analyzed heat flows in typical residential water heating systems. Their results indicate that thermal losses account for approximately 30 percent and 50 percent of all water heating energy consumption, for electric and gas-fired water heaters respectively. (Oil-fired water heaters operate at an efficiency near that for gas-fired units of similar design). These losses can be substantially reduced through water heater redesign or modification, resulting in higher water heater operating efficiencies and net reductions in total water heating energy consumption.

It was the objective of this investigation to evaluate several water heater modifications that might reduce water heater losses and energy use. The energy-saving options selected for study were reduced thermostat settings, increased and improved thermal insulation, intermittent ignition (for gas-fired units), and flue dampers (for gas- and oil-fired units). Projected energy savings were determined from tests on a selected group of nine water heaters. Because most available residential water heaters differ substantially only in the source of heat and the storage volume [1], test results are expected to be representative of typical water heaters in the field.

Evaluation of each modification was based on laboratory tests, utilizing the Department of Energy (DOE) water heater test procedure [3] where applicable, and other means of testing as required. In addition, the thermal losses from typical water heater fittings were measured. Results obtained in this study were in good agreement with energy-saving estimates reported in the literature $[1,2]$.

All testing was conducted at the National Bureau of Standards in the Product Performance Engineering Division of the Center for Consumer Product Technology. This work was performed in conjunction with work sponsored by the Department of Energy (formerly the Federal. Energy Administration) pertaining to water heater test method development.

\footnotetext{
* Numbers in brackets indicate references in Section 7
} 


\section{ENERGY CONSERVING MODIFICATIONS}

\subsection{Reduced Thermostat Settings}

Most residential water heaters are equipped with adjustable thermostats. Without any extra cost or modification to the water heater, energy savings can be realized by reducing the thermostat setting for normal operation and turning the thermostat down even further or turning the water heater off during extended non-demand periods.

Water at approximately $60^{\circ} \mathrm{C}$ to $71^{\circ} \mathrm{C}\left(140^{\circ} \mathrm{F}\right.$ to $\left.160^{\circ} \mathrm{F}\right) *$ is recommended by most dishwasher manufacturers for reasonable automatic dishwasher performance. Studies have shown that with some dishwashing machines, satisfactory performance can be obtained with water temperatures as low as $38^{\circ} \mathrm{C}(100 \mathrm{~F})$ [4]. All machines however, will not of fer acceptable cleaning at lower temperatures. In households equipped with such units thermostat reductions will be limited to the minimum temperature at which satisfactory performance is obtained. In homes without automatic dishwashers, water heater thermostats can be set even lower for normal operation, perhaps as low as $50^{\circ} \mathrm{C}\left(120^{\circ} \mathrm{F}\right)$. Minimum water heater storage temperatures are ultimately limited to the point at which the amount of thermal energy which can be delivered at the lower temperature is just sufficient to meet hot water needs.

Lowering the thermostat setting reduces water heater surface temperatures and thus all heat losses from the tank jacket, flue, exposed fittings, and service connections. Additional energy savings are realized due to a reduction in thermal energy delivered to fixed volume demands at the lower water temperature.

To consider the effect of thermostat setback on hot water energy delivery it must be recognized that a water heater satisfies two types of hot water demands: (I) an energy related demand in which a quantity of water at a desired temperature is obtained by mixing--for personal use such as a shower, and (2) a volume demand by which appliances such as clothes washers and dishwashers are supplied. The volume of hot water required to satisfy the energy related demand is dependent on the hot water supply temperature but the energy required in the delivered water is not. With a reduced storage temperature, water at any desired temperature and flow rate will still be obtained at a point of use by varying the amount of hot water used in proportion to the cold water. In contrast, the volume of hot water required to satisfy the volume demand is independent of supply temperature since the size of a draw is controlled by either a timer or volume control. It is here that additional savings are realized through thermostat setback.

The effect of thermostat setback on water heater standby loss was demonstrated in laboratory tests on several electric, gas-, and oil-fired water heaters, both before and after adding extra insulation.

*In cases where they are normally encountered in common usage, customary dimensional units have been included for clarification. 


\subsection{Insulation Improvements}

Thermal losses from stored hot water, through the water heater insulation and jacket, occur in all storage-type water heaters. These losses, termed jacket losses, occur continuously and constitute a major source of energy inefficiency. Through improvements in the water heater insulation via increasing insulation thickness, or improving insulation quality (lowering thermal conductivity), these losses may be reduced substantially.

Insulation thickness can be increased either by adding extra insulation (external to the jacket) after water heater installation, or by using thicker insulation during water heater manufacture. The former modification may be easily performed by a homeowner, using commercially available insulation retrofit kits or other types of appropriate insulation and following approved installation practices. The latter improvement must by made by the water heater manufacturer.

Improved insulation is of fered by several insulation manufacturers in various grades and thicknesses. Through the use of low conductivity insulation of standard thickness during water heater manufacture, significant reductions in jacket losses are possible. This insulation substitution requires no change in water heater dimensions or design, and would be a simple and cost effective means of energy conservation. Several water heater manufacturers now of fer energy efficient models with improved insulation. The use of low conductivity insulation of increased thickness offers even greater energy savings.

The effects of three different insulation changes on water heater losses were evaluated in laboratory tests. Each modification resulted in substantial energy savings.

\subsection{Decreased Pilot Input Rates}

The primary function of a pilot light in all gas appliances is to ignite a burner. In a gas-fired water heater (Figure 1), however, the continuous pilot also performs a second function--supplying heat to the stored water. Thermal energy is transferred from the pilot flame and hot products of combustion, through the tank bottom and flue walls, to the stored water. The transfer process is a complex one, dependent or several parameters. These include combustion chamber geometry, flue size and baffling, and pilot energy input rate. (See Section 6.4 for an assessment of the effects of pilot input rate). Each of these parameters influence, to varying extents, the amount of heat transferred to the stored water, and therefore water heater standby loss and energy consumption.

The pilot flame, as well as the hot wall of the flue column, induces air movement through the flue column. Air flow occurs as products of combustion and heated air in the flue rise up the flue due to increased buoyancy. Rising excess air (above that required for combustion of the pilot gas) carries away thermal energy from the stored water and pilot flame and contributes to water heater standby loss. Through a reduction in 
pilot energy input rate, a reduction in air flow and thus thermal losses may be realized. This modification was evaluated in laboratory tests on two different gas-fired water heaters.

\subsection{Intermittent Ignition and Flue Dampers}

Flue losses from gas- and oil-fired water heaters typically account for about one-third of water heating energy consumption. These losses can be reduced by several means, including elimination of the continuous pilot in gas-fired water heaters, and the use of flue dampers in gas- and oilfired water heaters.

The pilot's contribution to energy consumption in gas-fired water heaters may be eliminated by replacing the pilot with an intermittent ignition system. An intermittent ignition device performs the function of igniting the main burner, without requiring continuous energy input during burner "off" periods as the pilot does. Use of intermittent ignition by itself does not eliminate flue losses. The flue remains unrestricted and continues to lose heat as a result of a buoyancy effect within the flue column and exhaust duct. Through use of the intermittent ignition system however, losses due to pilot-induced air currents may be eliminated.

Pilot-induced air flow may be reduced by a second means, namely, the addition of a thermal flue damper in the water heater exhaust vent (see Figure 1). Operation of the thermal damper is quite simple. When the main burner is off, the thermal damper restricts air passage through the water heater flue column, while still permitting pilot combustion products to safely leak through the damper. This leakage or venting occurs through small slits in several flexible, thermally-actuated damper plates, which are closed at the time. When the main burner ignites, the heat of combustion products causes the damper plates to open, allowing unrestricted flow of exhaust gases. Because the thermal damper does not create an airtight seal, it is only partially effective in reducing losses through the vent. It will operate in conjunction with a continuous pilot however, and offers energy savings with or without the use of an intermittent ignition system.

Greater reductions in water heater flue loss are possible with a mechanical-type flue damper. A mechanical damper, similar to a butterfly valve, is installed at the flue exit of the water heater. When installed in location $B$ shown in Figure 1 , the damper is commonly referred to as a flue damper, whereas when installed at location A it is called a vent or stack damper. The damper is automatically actuated when the main burner cycles. When open (burner on), the damper allows products of combustion to be safely vented, but when closed it blocks air flow through the water heater flue, thus decreasing flue losses.

Ideally, the damper plate completely blocks all air passage through the flue when the main burner is off. For this reason an intermittent 
ignition system would be required for gas-fired water heaters equipped with such a damper.

Use of any type of flue damper with water heaters is currently prohibited by ANSI standards. However, a mechanical-type damper, which requires that the flue be open before gas will flow to the burner, may soon be permitted.

The energy saving potential of intermittent ignition systems was denonstrated in laboratory tests on three gas-fired water heaters. The effect of adding flue dampers was also determined for these units and for an oil-fired water heater.

\subsection{Thermal Losses From Water Heater Fitting}

Current water heater manufacturing practices provide for a layer of thermal insulation between the water tank and outer jacket. But this insulation is not extended to cover fittings or connections external to the jacket, such as temperature-pressure relief valves, tank drain valves, and exposed thermostat housings. These fittings and connections are often metallic and in effect constitute "thermal leaks" or low resistance paths through which heat escapes. The elimination of these losses offers potential savings in both energy and operating expense. In order to determine their contribution to total losses during standby, the thermal losses from typical fittings were measured in the laboratory. Energy saving modifications to these fittings were not attempted.

\section{LABORATORY FACILITIES}

Water heater tests were conducted in a laboratory designed specifically for this purpose. The laboratory consisted of four separate water heater test stations; two for electric water heaters and two for gasor oil-fired units. The latter stations were equipped with exhaust vents which reduced the clearance above the test units to less than $1.5 \mathrm{~m}$. Because of this reduced clearance, gas-fired water heaters were tested without a vent pipe installed above the draft diverter - a minor deviation from the DOE test procedure.

A variety of controls and instrumentation were utilized in the water heater studies. Power was supplied to each electric water heater from a regulated power supply at $240 \mathrm{~V}$, in accordance with manufacturers' installation instructions. Electrical energy input to each water heater was measured using a watt-hour meter having a 10 watt-hour resoiution.

Natural gas consumption of each gas-fired water heater was measured using a precision wet-test meter equipped with a pressure gage and thermometer. The heating value of the natural gas was measured and recorded by a continuously operating calorimeter. The higher heating value* ranged from 37.7 to $38.8 \mathrm{~kJ} / \mathrm{L}$ (1010 to $1040 \mathrm{Btu} / \mathrm{ft}^{3}$ ) but was typically $37.9 \mathrm{~kJ} / \mathrm{L}\left(1015 \mathrm{Btu} / \mathrm{ft}^{3}\right)$.

* The higher heating value is that measured when the products of combustion in a calorimetry test are condensed and cooled to the initial temperature $-5-$ 
Fuel oil (No. 2) was supplied to oil-fired water heaters from a reservoir mounted on a precision electronic scale. The specific gravity and heating value of the fuel oil was determined by calorimetry tests on a sample taken from the main fuel storage tank. The higher heating value of the fuel used was approximately $45.3 \mathrm{MJ} / \mathrm{kg}(19,500 \mathrm{Btu} / \mathrm{lbm})$.

Stored water temperatures, as well as ambient air temperature, were recorded for the duration of each test using either a multipoint temperature recorder or a minicomputer data collection system. The multipoint recorder employed Type T (copper-constantan) thermocouples and sampled temperatures several times per minute for the duration of each test. Type K (chromel-alumel) thermocouples were used with the minicomputer system, which measured and recorded temperatures at 2 minute intervals during recovery efficiency tests and at 15 minute intervals during standby tests.

\section{TEST PROCEDURES}

Each water heater tested was equipped with six thermocouples. These were located within the water tank, one at the level of the center point of each of six sections of equal volume, from top to bottom of the tank. The stored water temperature was computed as the arithmetic mean of the six thermocouple readings. Average temperatures during tests were computed as the arithmetic means of temperature samples taken at equally spaced intervals.

Water heater performance was evaluated in the laboratory by determining the efficiency at which the water heater performed each of two primary functions, namely, heating water and storing the hot water. Inservice water heating energy requirements were projected based on these tests.

The recovery efficiency test is used to measure the efficiency at which input energy to the water heater is utilized in raising the stored water temperature. In this test the water heater is filled with cold water at about $21^{\circ} \mathrm{C}\left(70^{\circ} \mathrm{F}\right)$. The heater is then energized and allowed to operate through a temperature rise of approximately $50^{\circ} \mathrm{C}\left(90^{\circ} \mathrm{F}\right)$. Recovery erficiency for gas- and oil-fired water heaters is calculated from the equation

$$
E_{r}=\frac{V \rho C_{p}\left(T_{f}-T_{i}\right)}{Q_{r}}
$$

where $E_{r}=$ recovery efficiency (dimensionless),

$$
\begin{aligned}
& v=\text { tank volume }(\mathrm{L}), \\
& \rho=\text { density of water--taken to be } 0.989 \mathrm{~kg} / \mathrm{L}(8.25 \mathrm{lbm} / \mathrm{gal}), \\
& C_{p}=\text { specific heat of water -- taken to be } 4180 \mathrm{~J} / \mathrm{kg}^{\circ} \mathrm{C}\left(1.0 \mathrm{Btu} / 1 \mathrm{bm}{ }^{\circ} \mathrm{F}\right),
\end{aligned}
$$


$\mathrm{T}_{\mathrm{f}}=$ stored water temperature at end of test $\left({ }^{\circ} \mathrm{C}\right)$,

$\mathrm{T}_{i}=$ stored water temperature at start of test $\left({ }^{\circ} \mathrm{C}\right)$, and $\begin{aligned} Q_{r}= & \text { total input energy consumed during the recovery efficiency } \\ & \text { test }(J) .\end{aligned}$

Thermal losses through the water heater jacket and fittings occur during the recovery efficiency test. As a result, recovery efficiency reflects combustion efficiency, thermal losses through the vent, and jacket losses during recovery.

A recovery efficiency of 100 percent was assumed for all electric water heaters tested (all had immersed heating elements). The recovery efficiency of an electric water heater is actually less than 100 percent because heat is lost from the stored water during recovery; however, these losses constitute only a small fraction (typically less than 2 percent) of the total energy added during the recovery test.

All water heater modifications evaluated in this study were aimed at reducing water heater storage (standby) losses, and did not significantly alter the efficiency at which heat is added to stored water. Hence, recovery efficiency needed only to be evaluated initially.

The losses incurred in storing hot water (standby losses) were evaluated in accordance with the DOE test procedure for measuring standby loss [3]. Standby loss for electric, gas- and oil-fired water heaters is calculated from the equation

$$
S=\frac{Q_{S}+\frac{V \rho C_{p}\left(T_{i}-T_{f}\right)}{E_{r}}}{t V \rho C_{p}\left(T_{W}-T_{a}\right)} \times 100
$$

where

$S=$ water heater standby loss $(\% / h)$,

$Q_{S}=$ total input energy consumed during the standby loss test $(J)$,

$t=$ duration of standby loss test $(h)$,

$\mathrm{T}_{\mathrm{W}}=$ average stored water temperature during test $\left({ }^{\circ} \mathrm{C}\right)$, and

$\mathrm{T}_{\mathrm{a}}=$ average ambient air temperature during test $\left({ }^{\circ} \mathrm{C}\right)$.

In this form, standby loss, $S$, represents the total input energy required per hour to maintain an average stored

water temperature; it is given here as a percentage of the heat content of the stored water above ambient air temperature. 
An alternate method of determining standby loss was utilized when evaluating the effect of gas pilot elimination and the use of mechanical flue dampers. This method, used in lieu of manually operating the main burner and blocking the flue column, is based on the construction of a typical water heater standby cycle from water heater recovery and cool-down profiles (Figure 2). It results in the following expression for standby loss

$$
S=\frac{T_{\text {max }}-T_{\text {min }}}{\left(T_{w}-T_{a}\right)\left(t_{c}+t_{b}\right) E_{r}^{\prime}} \times 100
$$

where

$\mathrm{I}_{\max }=$ stored water temperature at thermostat cut-off $\left({ }^{\circ} \mathrm{C}\right)$, $\mathrm{T}_{\text {min }}=$ stored water temperature at thermostat cut-on $\left({ }^{\circ} \mathrm{C}\right)$,

$t_{c}=\underset{\text { duration of water heater cool-down period in standby }}{\text { mode }(h) \text {, }}$

$t_{b}=$ duration of burner heating period in standby mode $(h)$, and $E_{r}^{\prime}=$ cyclic recovery efficiency -- value of recovery efficiency $=\frac{\mathrm{V} \rho C_{p}\left(T_{\max }-T_{\min }\right)}{Q_{r}}$

The importance of Equation 3 is that it lends itself to the calculation of standby loss based only on water heater operating temperatures and the results of two simple independent water heater tests, namely cyclic recovery efficiency and cool-down tests. A derivation of this equation is presented in Appendix $A$.

It should be noted that the value of cyclic recovery efficiency used in Equation 3 is obtained for a temperature rise from $T_{\text {min }}$ to $T_{\text {max }}$ rather than the $50^{\circ} \mathrm{C}$ temperature rise specified in the DOE test procedure for the standard recovery efficiency. The variation in recovery efficiency with temperature rise per cycle is illustrated in Figure 3 for one gas-fired water heater tested. As shown, the cyclic recovery efficiency is about 5 percentage points lower than the standard recovery efficiency for this water heater.

For the purpose of determining water heater standby loss, use of the cyclic recovery efficiency, $E_{r}$, with Equation 3 gives good agreement with values of standby loss determined using $E_{r}$ in Equation 2.* Herce, $E_{r}^{\prime}$ was utilized in all simulated standby loss test calculations.

\footnotetext{
*Any error which might be introduced by using the standard rather than the cyclic recovery efficiency in the energy correction term in Equation 2 is minimized by beginning and ending the test calculation at $T_{i} \approx T_{f}$. Under these conditions, standby loss calculations using Equation 2 are essentially independent of small variations in measured values for recovery efficiency.
} 
Upon laboratory determination of water heater standby loss and recovery efficiency and the assignment of values to water usage variables, the energy consumption of a water heater, in actual use, can be estimated. Daily water heating energy requirements are related to water heater characteristics and hot water use conditions through the relation

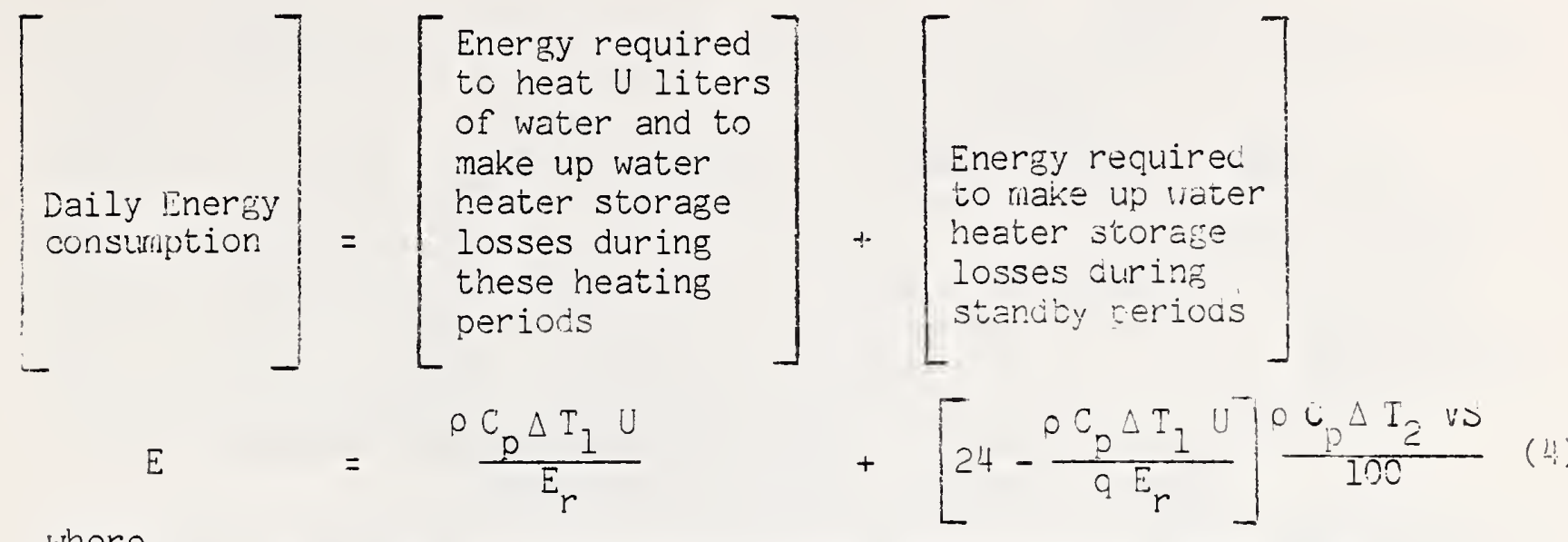

where

$E=$ total input energy consumed per day by water heater (energy content of unburned fuel and electric input), (J/day),

$U=$ daily hot water usage rate (L/day),

$\Delta \mathrm{T}_{1}=\underset{\text { difference between water heater inlet and outlet }}{\text { terneratures }(\mathrm{C}) \text {, }}$

$\Delta T_{2}=$ difference between average stored water temperature a:ld ambient air temperature $\left({ }^{\circ} \mathrm{C}\right)$,

$q=$ energy input rate to main burner or heating element (ki ).

Using the DOE test procedure values ot'

$$
\begin{aligned}
U & =243 \mathrm{~L} / \text { day }(64.3 \text { gal/day }), \\
\Delta T_{1} & =50^{\circ} \mathrm{C}\left(90^{\circ} \mathrm{F}\right), \text { and } \\
\Delta T_{2} & =50^{\circ} \mathrm{C}\left(90^{\circ} \mathrm{F}\right),
\end{aligned}
$$

in Equation 4 allows the daily energy requirements to be expressed as a function of water heater characteristics alone.

The energy saved through a thermostat setback was determined using the following equation which gives daily water heating energy requirements as a function of water heater usage parameters. This equation is a modification of Equation 4 and is derived in Appendix B. For a $0^{\circ} \mathrm{C}$ thermostat setback, that is, $\Delta \mathrm{T}_{1}^{\prime}=\Delta \mathrm{T}_{1}$, Equation 5 reduces to Equation 4 . 


$$
E=\left[A-B\left(\Delta T_{1}^{\prime}-\Delta T_{a}\right)\right]\left[\phi \Delta T_{1}^{\prime}+(1-\phi) \Delta T_{1}\right]+C\left(\Delta T_{1}^{\prime}-\Delta T_{a}\right)
$$

where the constants $A, B$, and $C$ are given by the expressions

$$
\begin{aligned}
& A=\frac{\rho C_{p} U}{E_{r}}, \\
& B=\frac{\left(\rho C_{p}\right)^{2} U V S}{100 q E_{r}} \text {, and } \\
& C=0.24 \rho C_{p} V S
\end{aligned}
$$

with

$U$ = daily hot water usage rate before thermostat setback -taken to be 243 L/day (64.3 gal/day),

$\Delta \mathrm{T}_{1}=$ difference between water heater inlet and outlet temperatures before thermostat setback -- taken to be $50^{\circ} \mathrm{C}\left(90^{\circ} \mathrm{F}\right)$, and

$\Delta T_{I}^{\prime}=$ difference between water heater inlet and outlet temperatures after thermostat setback $\left({ }^{\circ} \mathrm{C}\right)$,

$\Delta \mathrm{T}_{\mathrm{a}}=$ difference between ambient air temperature and inlet water temperature -- taken to be zero, and

$\phi=$ fraction of hot water going to clothes washer and dishwasher -- taken to be 0.3 .

Water heating energy consumption, as calculated from Equation 4 or 5 , does not account for any interactions with the space heating or cooling systems. Separate calculations involving standby loss, flue loss, duration of space heating and cooling seasons and other parameters would be required to calculate the impact of the water heating system on the total energy consumption of a building.

In the laboratory, water heater standby loss was determined both before and after each modification. Recovery efficiency was essentially unaffected by any of the modifications performed and was therefore measured only initially. The effect of each modification on energy usage was then evaluated using the previous equations.

\section{TEST RESULTS}

Nine water heaters, representing standard and "energy-saving" models currently on the market, were obtained for testing. This collection was comprised of several standard models of each water heater type -- electric, gas-fired, and oil-fired -- as well as one electric and one gas-fired "energy saving" model. Some characteristics of these water heaters are 
presented in Table 1. Notable features of the energy-saving models included increased thermal insulation and an integral heat trap for the electric model, as well as improved insulation, reduced pilot rate, and reduced burner input rate for the gas-fired model.

A summary of potential energy savings is given in Table 2 for the various modifications which were evaluated. Results indicate that through a combination of two easily performed water heater modifications -reducing thermostat setting and adding extra insulation -- energy consumption may be reduced dramatically. Energy savings of about 18 percent were obtained for the gas- and oil-fired models tested, while an 11 percent reduction was realized for the energy-conserving electric model. Energy savings slightly higher than 11 percent are expected for standard electric water heaters undergoing this combined modification. Additional savings may be realized for gas- or oil-fired units by adding flue dampers. Energy requirements for these models might be reduced by as much as 30 percent with all three modifications.

It should be noted that all estimates of energy savings presented in this study are based on a small sample size (in many cases one test unit). Most (standard) residential water heaters do not differ substantially with regards to energy features such as thermal insulation or flue design however, and a large sample size is not necessary. Good agreement between test results obtained and estimates of energy savings presented in the literaure $[1,2]$ reinforce this fact.

\subsection{Reduced Thermostat Settings}

To evaluate the effect of reduced thermostat settings on water heater losses, standby loss tests were conducted on electric, gas-, and oil-fired water heaters operating at thermostat settings of approximately $70^{\circ} \mathrm{C}$ $\left(160^{\circ} \mathrm{F}\right)$. The thermostat settings were then reduced to about $60^{\circ} \mathrm{C}\left(140^{\circ} \mathrm{F}\right.$ ) and the tests were repeated. Only the setting of the lower thermostat was reduced for electric units since this thermostat controls stored water temperature. Standby loss tests were performed on water heaters both with and without extra insulation added. Test results are presented in Table 3 along with total reductions in water heating energy requirements as determined using Equation 5. These reductions include energy savings due to both reduced thermal losses during standby and reduced thermal energy delivered for fixed-volume demands. The latter accounts for approximateiy $1 / 3$ of the total energy savings that are realized through thermostat setback (see Agpendix B). As indicated in Table 3, a thermostat setback of about $10^{\circ} \mathrm{C}\left(18^{\mathrm{F}}\right)$ resulted in energy savings of 11,13 , and 12 percent for standard electric, gas-, and oil-fired water heaters (without extra insulation) respectively. Reductions slightly less than these were obtained for the water heaters with added insulation, after thermostat setback. Energy savings of 9 percent were realized for the energy conserving electric unit after undergoing this change. 
It can be seen from Table 3 that lowering thermostat settings does not significantly change the water heater standby loss (S). This indicates that the heat transfer resistance between the energy of the stored water and the ambient surroundings is essentially temperature independent, as would be expected for temperature changes of only $10^{\circ} \mathrm{C}$. For a $5.6^{\circ} \mathrm{C}$ ( $10^{\circ} \mathrm{F}$ ) thermostat setback then, energy savings of 5 percent and 6 percent are expected for standard electric, and gas- and oil-fired water heaters.

\subsection{Insulation Improvements}

The effect of insulation improvements on water heater standby loss and energy consumption was demonstrated in laboratory tests on several water heaters. The original insulation in all standard water heaters tested was "single density" fiberglass of nominal $25 \mathrm{~mm}$ ( 1 in) thickness. The thermal conductivity of this type insulation is about $0.042 \mathrm{~W} / \mathrm{m} \cdot \mathrm{K}\left(0.024 \mathrm{Btu} / \mathrm{h} \cdot \mathrm{ft} \cdot \mathrm{F}_{\mathrm{F}}\right)[1]$. water heater insulation was improved through three different changes, namely: (1) the addition of extra insulation, (2) the replacement of the original water heater insulation with improved insulation (Iower thermal conductivity) of the same thickness, and (3) the replacement of the original water heater insulation with improved insulation of increased thickness.

\subsubsection{Added Insulation}

Extra insulation was added in the form of commercially available insulation retrofit kits. These kits consist of a piece of $38 \mathrm{~mm}$ ( $1.5 \mathrm{in}$ ) thick fiberglass insulation faced with vinyl fabric. The thermal conductivity of the insulation blanket is estimated to be about $0.050 \mathrm{~W} / \mathrm{m} \cdot \mathrm{K}$ $(0.023 \mathrm{Btu} / \mathrm{hr} \cdot \mathrm{ft} \cdot \mathrm{F})[5]$. The extra insulation was installed according to manufacturers' instructions, that is, each insulation blanket was cut to size, wrapped around the water heater jacket, and then taped in place. The insulation thickness, as installed, was about $33 \mathrm{~mm}$ ( $1.3 \mathrm{in}$ ).

Two electric (one an "energy conserving" model), one gas-, and two oil-fired water heaters were tested before and after adding extra insulation. Results of these tests are presented in Table 4 along with corresponding reduction in energy usage, as determined from Equation 4 . On the basis of these findings it appears that reductions in energy usage of approximately 7 to 9 percent may be realized for most standard electric, gas-, and oil-fired water heaters through the addition of extra insulation. Improvements obtained by adding extra insulation to energy conserving models (originally equipped with thicker insulation) may be much lower than for standard water heaters. A 2.6 percent reduction in energy usage was obtained for the energy conserving electric model as compared with a 7 percent reduction for the other electric water heater undergoing the same change. 


\subsubsection{Added Insulation and Reduced Thermostat Settings}

After adding extra insulation, several water heaters were tested at reduced thermostat settings. The effect of the combined modification -decreased thermostat setting and increased thermal insulation -- yielded impressive energy savings. As indicated in Table 5, reductions in energy consumption of 11 and 19 percent were realized for the energy saving electric and standard gas- and oil-fired water heaters tested. Energy savings somewhat higher than 11 percent are expected for standard electric models undergoing this combined modification. Note that the reduction in energy requirements for the combined modification is not equal to the sum of the reduction for each individual change, but is slightly less.

\subsubsection{Decreased Thermal Conductivity of Insulation}

In the second insulation modification, the original water heater insulation was replaced with low conductivity insulation of the same thickness. The thermal conductivity of this insulation is about $0.031 \mathrm{w} / \mathrm{m} \cdot \mathrm{K}(0.018 \mathrm{Btu} / \mathrm{h} \cdot \mathrm{ft} \cdot \mathrm{F})[6]$. No extra insularion was used in conjurction with the improved insulation for this first test. The benefit of replacing original water heater insulation with improved insulation of the same thickness was demonstrated in tests on electric, gas- and oil-fired water heaters equipped with $25 \mathrm{~mm}$ ( 1.0 in) thick insulation. Results of these tests are presented in Table 6 and show trat decreases in standby loss,S, of about 15, 9 and 5 percent were realized after this change, for electric, gas- and oil-fired water heaters respectively. These decreases correspond to reductions in energy usage of 3.6 percent for the electric, 2.9 percent for the gas-fired, and 1.8 percent for the oil-fired water heater. It should be noted that since the improved insulation used was the same thickness as original insulation, its utilization would require no changes in water heater design or dimensions.

\subsubsection{Decreased Thermal Conductivity, Increased Thickness of Insulation}

The original insulation in two water heaters was replaced with commercially availabie insulation of $50 \mathrm{~mm}$ ( 2 in) thickness and thermal conductivity of $0.029 \mathrm{~W} / \mathrm{m} . \mathrm{K}(0.017 \mathrm{Btu} / \mathrm{h} \cdot \mathrm{ft} \cdot \mathrm{F})[6]$. After making this modification, the water heater jacket could not be reinstalled due to the increased insulation thickness. The insulation was taped in place and subsequent tests were conducted with the jacket removed. Test results, presented in Table 7 , indicate a significant potential for energy savings. For the electric, a decrease in standby loss, S, of 35 percent was observed after the insulation change. This corresponds to an 8.5 percent reduction in energy use. Similarly, a decrease in standby loss of 29 percent, corresponding to a 9.6 percent reduction in energy usage, was obtained for the gas-fired water heater. These improvements are of the same magnitude as those obtained by adding $38 \mathrm{~mm}$ ( 1.3 in) of extra insulation.

\subsection{Decreased Pilot Input Rates}

The potential for energy savings through reductions in gas pilot input rate was assessed based on tests on two gas-fired water heaters. The pilot 
input rate of each water heater was first measured "as received." The original thermostat was then replaced with one having a pilot adjustment capability, and tests at the original and several different pilot rates were conducted. The minimum pilot input rate of heater Gl, $88 \mathrm{~W}(300 \mathrm{Btu} / \mathrm{h})$, was limited by a pilot flame sensor (thermocouple) cut-of'f, but by repositioning the sensor closer to the pilot flame, a pilot input rate of $59 \mathrm{~W}(200 \mathrm{Btu} / \mathrm{h})$ was possible. The pilot input rate of water heater $\mathrm{G} 2$ was adjustable to $59 \mathrm{~W}(200 \mathrm{Btu} / \mathrm{h})$ without modifications to the flame sensor. Pilot input rates below $88 \mathrm{~W}(300 \mathrm{Btu} / \mathrm{h})$ may not be feasible in practice, however, due to chimney downdrafts which could extinguish the pilot flame. ANSI standards of updraft and downdraft tests, as weil as wind tests, will ultimately determine the minimum pilot size necessary.

Test results for both water heaters are presented in Table 8 and Figure 4 for various pilot rate reductions. These results indicate a trend toward lower values for standby loss at decreased pilot input rates, but the energy savings realized were not significant. For a reduction in pilot input rate from $200 \mathrm{~W}$ to $88 \mathrm{~W}(680 \mathrm{Btu} / \mathrm{h}$ to $300 \mathrm{Btu} / \mathrm{h})$, the standby loss, S, of water heater Gl decreased from 6.9 percent per hour to 6.7 percent per hour. This decrease corresponds to only a 0.8 percent reduction in water heating energy requirements. A further reduction in pilot input rate to 59 $W(200 \mathrm{Btu} / \mathrm{h})$, if safety requirements can be met, would result in water heating energy savings of 1.0 percent for this unit.

Water heater GI was also tested at a pilot input rate greater than the original rate. As shown in Table 8, except for pilot input rates below 130 $W(440 \mathrm{Btu} / \mathrm{h})$, standby loss for this water heater was essentially unaffected by changes in pilot input rate.

For water heater G2, a reduction in pilot input rate from $220 \mathrm{~N}$ to 88 $\mathrm{W}(750 \mathrm{Btu} / \mathrm{h}$ to $300 \mathrm{Btu} / \mathrm{h})$ resulted in a decrease in standby loss, $\mathrm{S}$, from 6.1 percent per hour to 5.9 percent per hour. This reduction corresponds to a 1.4 percent energy savings. A further reduction in pilot input rate to $59 \mathrm{~W}(200 \mathrm{Btu} / \mathrm{h})$ resulted in only a 1.8 percent decrease in water heating energy consumption.

\subsection{Intermittent Ignition and Flue Dampers}

It was the original objective of this investigation to evaluate the effect of gas pilot elimination and mechanical flue dampers through actual water heater modification, using commercially-available electric ignitors and dampers. As such items were not available for domestic water heaters, it was necessary to simulate the effect of these devices. Thermal dampers were obtained commercially and were evaluated in accordance with DOE standby test procedures.

Two different methods were utilized in determining water heater standby loss. In the first method, pilot elimination for gas-fired water heaters was simulated in the laboratory by manually igniting the main burner at the thermostat cut-on temperature $\left(\mathrm{T}_{\min }\right)$ and extinguishing the 
burner and pilot at the thermostat cut-off temperature ( $T_{\text {max }}$ ). The effect of a mechanical flue damper combined with intermittent ighition was simulated by additionally blocking the flue during periods in which the main burner was off.* Conducting the DOE standby loss test under these conditions, however, is a time-consuming task because water temperature must be monitored frequently, and burner ignition may be required during times when personnel are not available. For this reason, a second means of determining standby loss was utilized. This method is based on an energy balance on the water heater during a typical standby cycle (Figure 2) and results in an expression for standby loss in terms of water heater cooldown rate and cyclic recovery efficiency. These parameters may be measured independently and then substituted into Equation 3 to determine water heater standby loss.

The accuracy of Equation 3 was demonstrated in three separate tests. In the first test, the effect of pilot elimination on the standby loss of water heater GI was determined by manually igniting and extinguishing the burner at the proper time. Standby loss determined using this method was 6.23 percent per hour as compared to a value of 6.03 percent per hour calculated from Equation 3. The use of a mechanical flue damper in conjunction with electric ignition was then simulated by manuaily operating the burner and blocking the flue completely when the main burner was off. The result was a standby loss of 4.52 percent per hour. Standby loss obtained from Equation 3 was 4.53 percent per hour. Finally, the standby loss of water heater 01 (oil-fired) was calculated using Equation 3 . A value of 6.27 percent per hour was predicted. This was in excellent agreement with test results of 6.28 percent per hour. Equation 3 was used in the remaining tests.

Test simulations were performed on three gas and one oil-fired water heaters. Prior to simulating any modifications, the recovery efficiency and standby loss of each model was measured using DOE test procedures. The cyclic recovery efficiency of each water heater was then measured at various temperature rises. Cool-down experiments were conducted, and the time constants were evaluated with both the flue open and the flue blocked. Standby loss was predicted using Equation 3.

\subsubsection{Intermittent Ignition for Gas-Fired Units}

The results of tests simulating replacement of the continuous gas pilot with intermittent ignition are presented in Table 9 for two standard and one energy-saving water heater through pilot elimination. Through pilot elimination, reductions in total water heating energy use of 4 percent and 6 percent were realized for the standard gas-fired water heaters tested. A reduction of about 3 percent was obtained for the energy saving model tested. These estimates do not include any energy required to operate the ignitor.

It is interesting to note here that if the results of standby loss versus pilot input rate tests (Figure 4) were extrapolated to a zero input

*This is equivalent to a 100 percent effective flue damper, since no air passage occurs. 
rate, standby loss values of approximately 6.7 percent per hour and 5.7 percent per hour would be predicted for Units Gl and G2 respectively. Through actual tests on these units however, standby loss values of 6.0 percent per hour and 5.0 percent per hour were measured when the pilot was eliminated - significantly lower than the predicted values. This difference seems to indicate a discontinuity or extreme non-linearity at or near the zero input rate axis of Figure 4. The net result is that just the presence of a pilot has a greater effect on water heater standby loss than variations in the pilot input rate.

\subsubsection{Intermittent Ignition and Mechanical Flue Dampers for Gas-Fired Units}

The use of mechanical flue dampers in conjunction with intermittent ignition offers energy savings far greater than those obtained using intermittent ignition alone. As shown in Table 10, reductions in water heating energy use of 11 and 16 percent were realized for water heaters Gl and G2 after this modification. A decrease of 10 percent was measured for heater G3 (energy-saving model). These estimates were obtained from tests in which the flue was completely blocked during cool-down periods. Smaller reductions are expected for flue dampers which do not restrict air flow completely.

Comparison of the standby loss of heater GI when the exhaust stack is blocked above the draft diverter (simulating a stack damper) to that obtained when intermittent ignition alone is used (Table 9), indicates that the "flue damper" has a minimal effect in reducing water heater standby loss when installed as a stack damper (above the diverter). In this location however, it would be effective in reducing infiltration losses through the stack.

\subsubsection{Thermal Flue Dampers for Gas-Fired Waters Heaters}

The energy saving potential for commercially-available, thermal-type dampers was demonstrated in tests on each of the three gas-fired units. Thermal dampers allow normal operation of the continuous gas pilot, hence the DOE test procedure was utilized in all tests. The dampers were evaluated in their two possible installation locations -- above and below the draft diverters (locations $A$ and $B$ in Figure 1) -- that is, as stack dampers and as flue dampers.

Test results are presented in Table 11. These findings indicate that thermal dampers, like mechanical dampers, offer only small water heating energy savings when they are installed as stack dampers -- typically less than 1 percent. When installed as flue dampers they offer substantially greater water heating energy savings -- 4 percent and 3 percent for standard and energy saving gas-fired units respectively. 
The use of a flue damper on an external-flue, oil-fired water heater was also simulated in the laboratory. The effect of the damper on standby loss was determined for two water heater conditions; as received, and with extra insulation installed. Results are given in Table 12. Reductions in energy use of 14 percent and 9 percent were realized after adding a damper, for the original and insulated condition respectively. When equipped with extra insulation and a flue damper, the standby loss for the water heater was nearly half its original value.

\subsection{Thermal Losses From Water Heater Fittings}

Determination of the thermal losses from exposed water heater fittings was made using an indirect, comparative method of measurement. In this method the total heat loss from a 75-liter (20 gal) electric water heater was determined both with the test fitting installed and with the fitting removed. The difference in the measured heat loss was attributed to the fitting losses.

The thermal losses from water heater temperature-pressure relief valves (TPRV) and thermostats were measured in the laboratory using this comparative method and the apparatus shown in Figure 5 . In these tests, a variable power supply was used to apply constant electrical power to the electric water heater, on which test fittings were installed. With the application of power, the system temperature increases until an equilibrium temperature (a function of power input and thermal losses) is reached. At this point, the power input is equal to the total heat loss from the system. By taking measurements at various power input levels then removing the fitting and repeating the procedure again, the thermal losses of each fitting were determined.

Heat loss test results are presented in Figure 6 for a temperaturepressure relief valve. In this Figure the power input to the test fixture is plotted against the equilibrium tank temperature above ambient for both the TPRV installed and TPRV removed. At a given tank temperature above ambient, the heat lost by the TPRV is the difference between the power input with TPRV installed and the power input with TPRV removed. Based on this measurement, the thermal losses from a TPRV are about $4 \mathrm{~W}$ ( $14 \mathrm{Btu} / \mathrm{h}$ ) at a stored water temperature of $40^{\circ} \mathrm{C}\left(72^{\circ} \mathrm{F}\right)$ above ambient. Losses from metallic tank drain valves are expected to be about half the losses from a TPRV because the valve is located closer to the tank bottom where the stored water is coolest, and because the exposed area of a drain valve is approximately one-half that of a TPRV.

Losses from a gas-fired water heater thermostat and associated plumbing were measured also using the comparative test method. These losses are about $10 \mathrm{~W}(34 \mathrm{Btu} / \mathrm{h})$ at a stored water temperature $40^{\circ} \mathrm{C}$ above ambient. An oil-fired water heater thermostat was also tested in the 
laboratory. The losses from the unit were approximately $4 \mathrm{~W}(14 \mathrm{Btu} / \mathrm{h})$ at a stored water temperature of $40^{\circ} \mathrm{C}$ above ambient.

Thermal losses from exposed fittings and connections may be reduced through use of thermal insulation, where safety is not compromised, or through use of replacement fittings having decreased thermal conductivity. These modifications were not evaluated in the laboratory.

\section{SUMMARY AND CONCLUSIONS}

Reducing water heater thermostat settings is one of the most effective means of saving energy. For the most common types and sizes of domestic water heaters, the expected energy saving is approximately 10 percent for electric models and 12 percent for gas or oil-fired models when a $10^{\circ} \mathrm{C}$ thermostat setback is utilized.

Standby loss and thus water heating energy usage is substantially reduced by improving jacket insulation. Adding insulation blankets results in energy savings of 7 to 9 percent for standard electric, gas-, and oilfired water heaters. The direct replacement of original insulation with thicker and lower conductivity material offers similar reductions. Potential savings for "energy-saving" water heaters, are about 3 percent -somewhat less than for standard models.

Reductions in pilot input rate decrease water heater standby loss only slightly. Energy savings of from 0.8 to 1.4 percent were realized for a pilot reduction from about $220 \mathrm{~W}$ to $88 \mathrm{~W}(750 \mathrm{Btu} / \mathrm{h}$ to $300 \mathrm{Btu} / \mathrm{h})$. Further pilot reductions to $60 \mathrm{~W}(200 \mathrm{Btu} / \mathrm{h})$ resulted in additional savings of less than one-half percent.

Replacement of gas pilots with intermittent ignition offers considerably greater savings than pilot rate reduction. Energy savings of about 5 percent were achieved through the elimination of continuous pilots in standard gas-fired water heaters. Smaller improvements (3 percent) were observed for the "energy-saving" model tested.

Use of mechanical flue dampers in conjunction with intermittent ignition is one of the most attractive combined modifications for gas-fired water heaters. Water heating energy savings of from 11 to 16 percent and 10 percent can be expected for standard and energy-conserving gas-fired water heaters undergoing this combined modification. Thermal flue dampers, operating in conjunction with continuous gas pilots, offer smaller energy savings -- about 4 percent for standard and 3 percent for "energy-saving" gas-fired water heaters. When installed as stack dampers, both mechanical and thermal type dampers offer little water heating energy savings.

Uninsulated water heater fittings and connections, although small in area compared to the total tank area, account for substantial losses. Thermal losses at a stored water temperature $40^{\circ} \mathrm{C}\left(72^{\circ} \mathrm{F}\right)$ above ambient are 
approximately $4 \mathrm{~W}(14 \mathrm{Btu} / \mathrm{h})$ for a temperature-pressure relief valve, I0 $\mathrm{W}$ $(34 \mathrm{Btu} / \mathrm{h})$ for a gas-fired water heater thermostat and $4 \mathrm{~W}(14 \mathrm{Btu} / \mathrm{h})$ for an oil-fired water heater thermostat. Thermal losses of the drain valve are estimated to be $2 \mathrm{~W}(7 \mathrm{Btu} / \mathrm{h})$ under similar hot water storage conditions.

All results obtained in this study are in general agreement with what energy saving estimates are reported in the literature $[1,2]$. In conclusion, it should not be assumed that the potential savings from making all possible modifications will be the sum of the individual savings measured. As results presented in Table 2 indicate, multiple modifications have interacting effects and result in slightly smaller overall savings. 


\section{REFERENCES}

(1) Arthur D. Little, Inc., Study of Energy Saving Options for Refrigerators and Water Heaters, May 1976.

(2) Hoskins, Robert A. and Hirst, Eric, "Energy and Cost Analysis of Residential Water Heaters," Oak Ridge National Laboratory, ORNL/CON10, June 1977.

(3) Energy Conservation Program for Appliances, Test Procedures for Water Heaters, Federal Register, Vol. 42, No. 192, October 4, 1977.

(4) Kanjeko, T.M. and Compton, J. W. "Low Temperature Home Machine Dishwashing, "Proceedings of the Conference on Major Home Appliance Technology for Energy Conservation, Purdue University, February 27 March 1, 1978.

(5) "Insulation Refit Kit for Domestic Water Heaters," Report prepared by Johns-Manville Sales Corporation for ERDA under Contract Nos. WA-763813 and WA-76-3814, March 23, 1977.

(6) Owens-Corning Fiberglass Corp., Thermal Conductivity Data. 


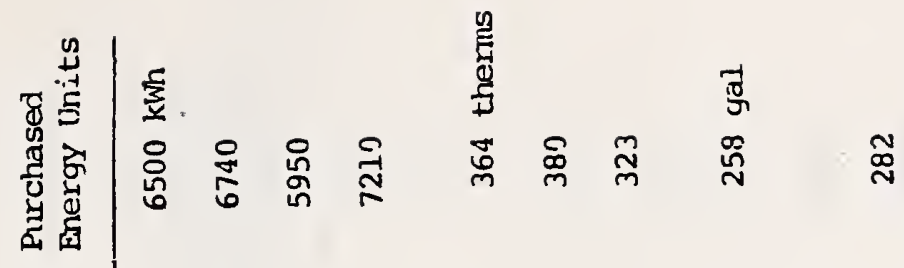

애

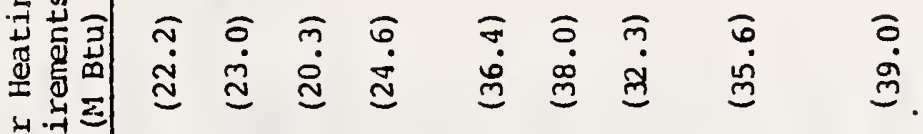

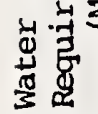

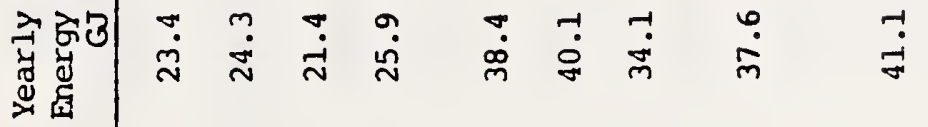

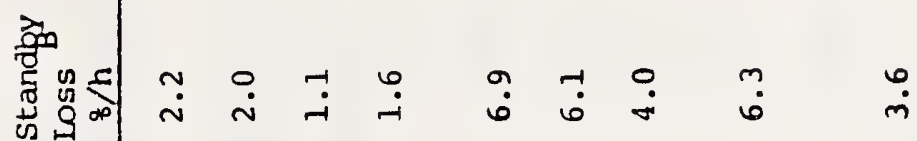

马्य

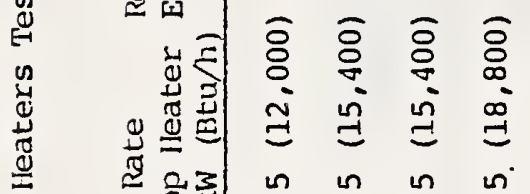

苟

$\begin{array}{llll}1 & 1 & 1 & 1\end{array}$

今

它苞焉

氙语

¿ิ

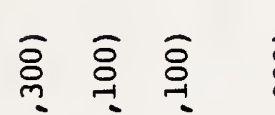

๙ิ

通立

$\ddot{n} \stackrel{0}{n} \stackrel{\dot{m}}{n}$

กั ก ก

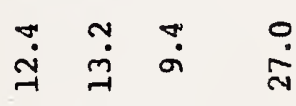

范

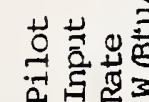

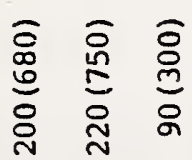

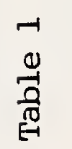

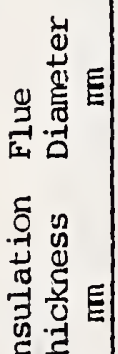

1111

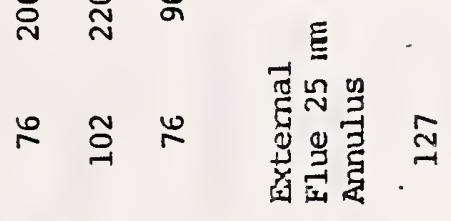

号

$\stackrel{\leftrightarrow}{\circ} \quad \ddot{\sigma}$

蓉 8

$\overbrace{\rightarrow \rightarrow-1}^{0}$

究

要

㝳岂

30

过

$\stackrel{n}{2}$ in

$\cong \stackrel{\sim}{\sim} \stackrel{n}{\sim}$

น

卷 胥

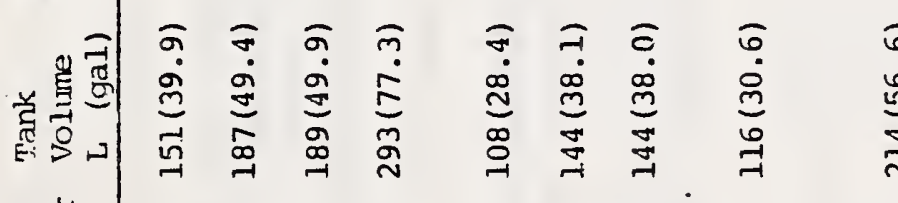

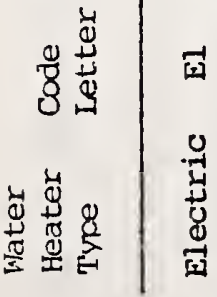

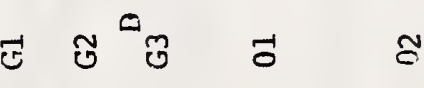

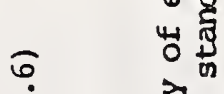

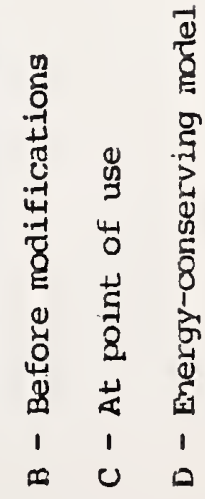




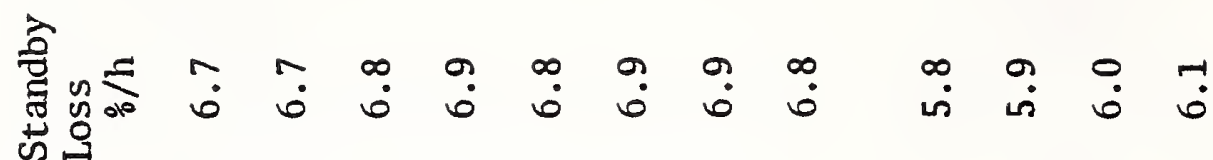

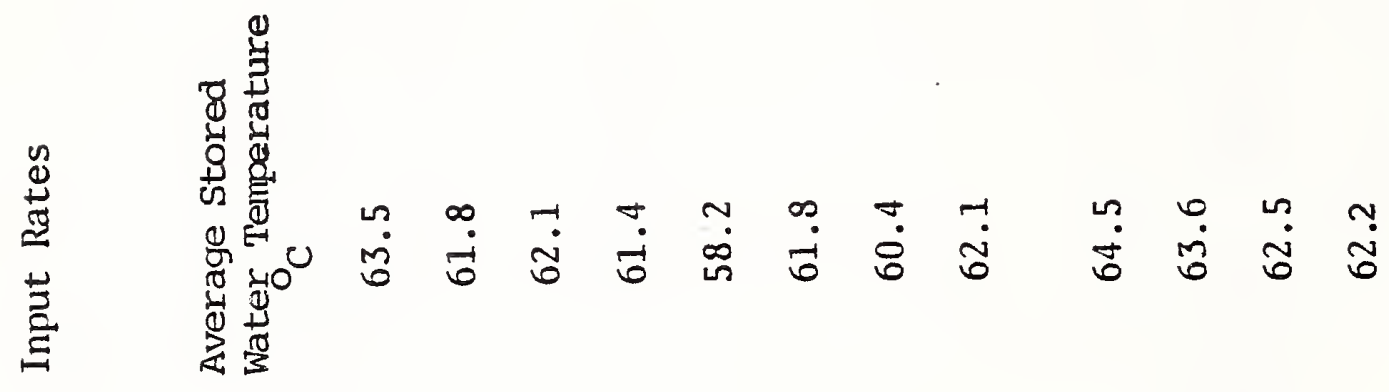

产

s.

莎

in

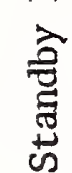

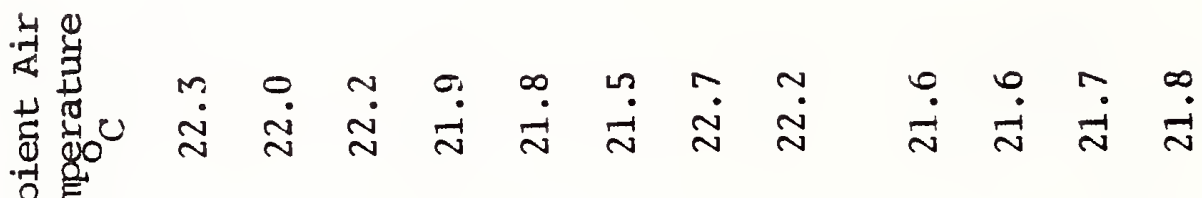

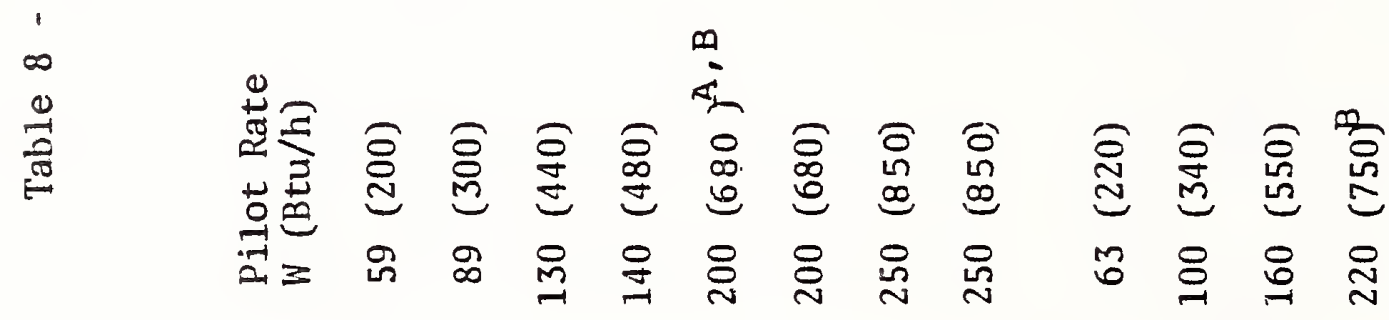

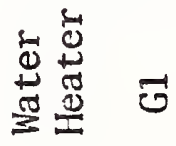

ชิ

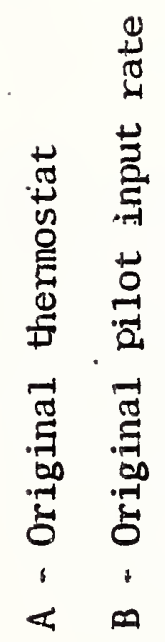




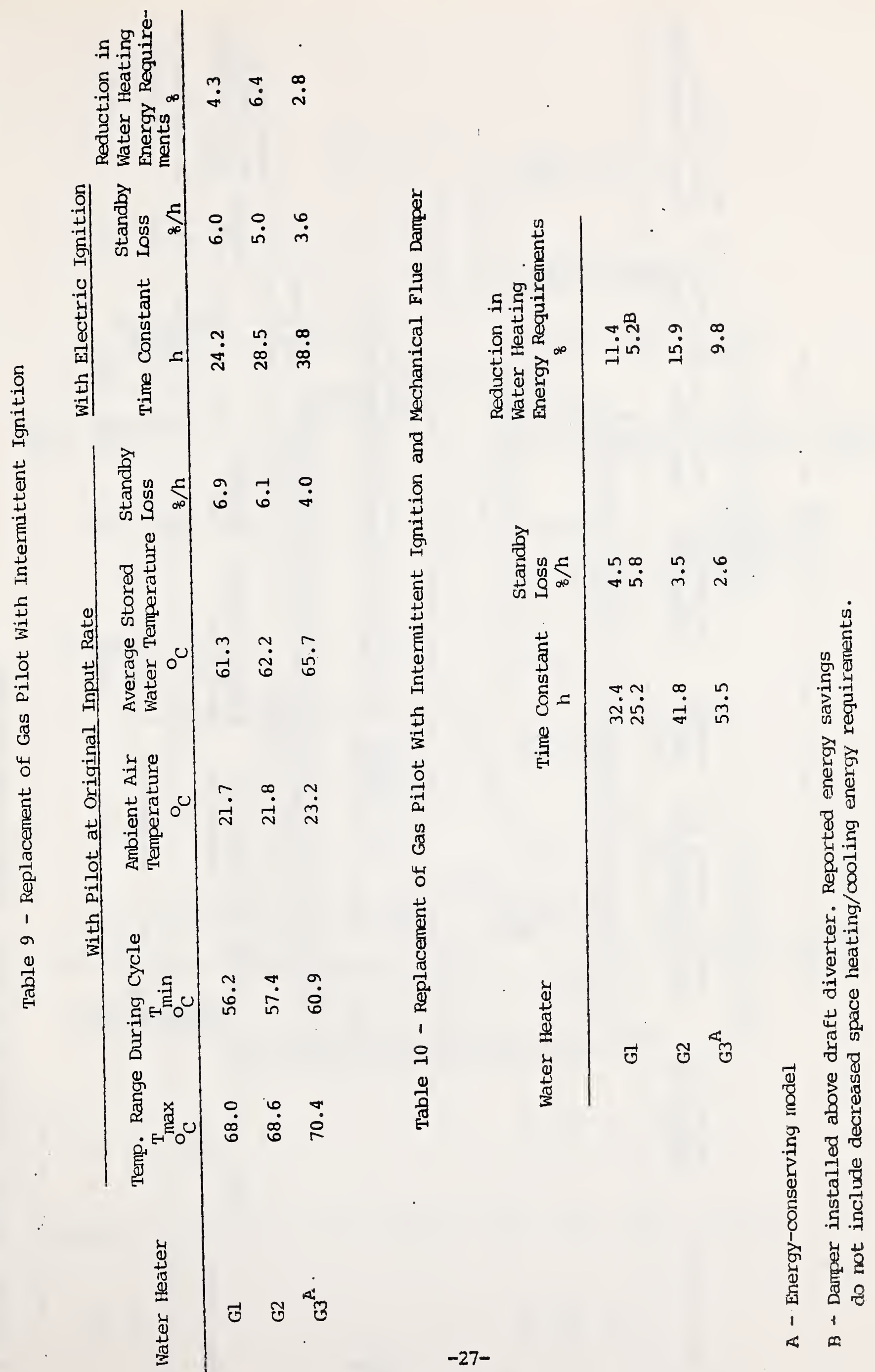




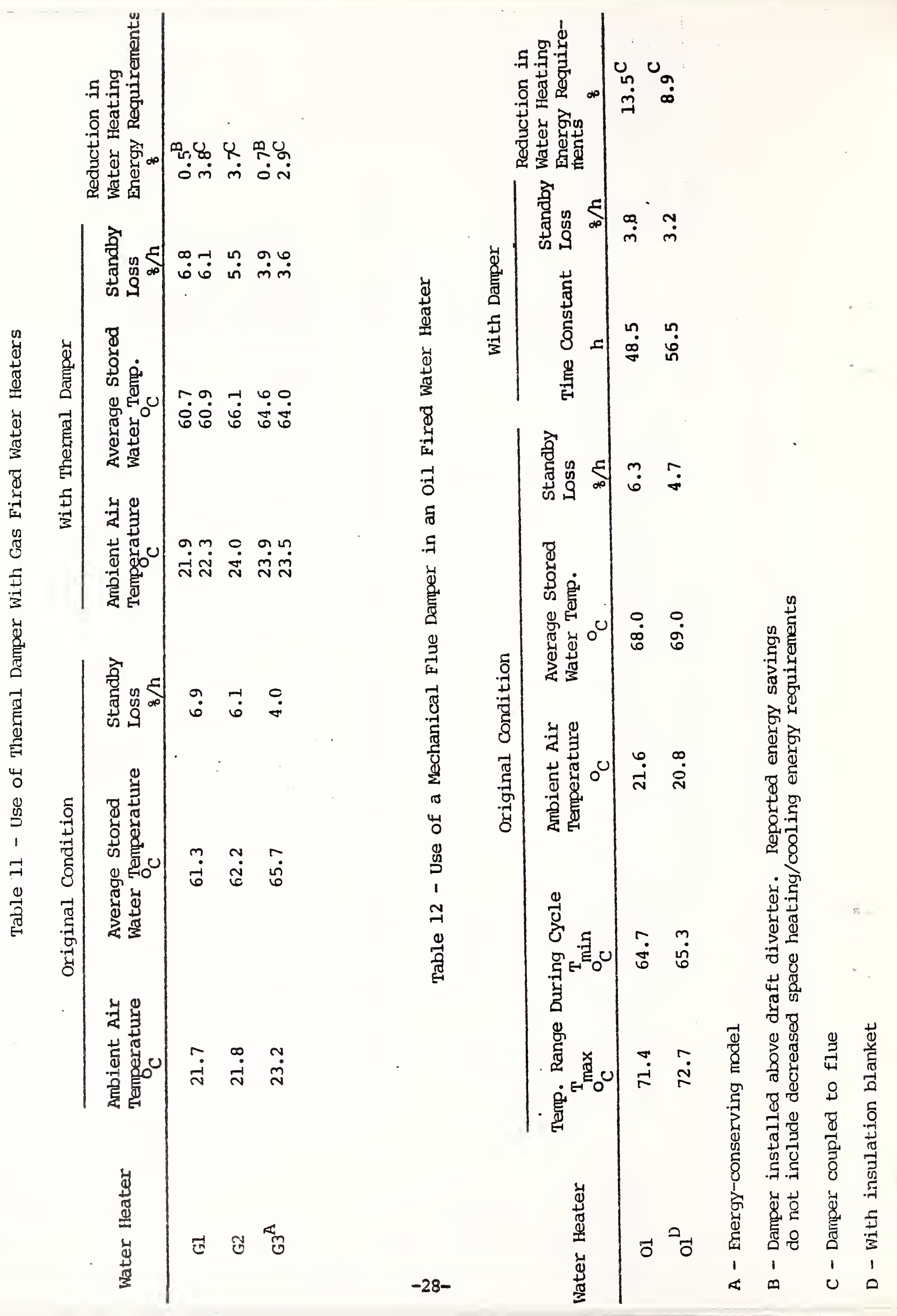




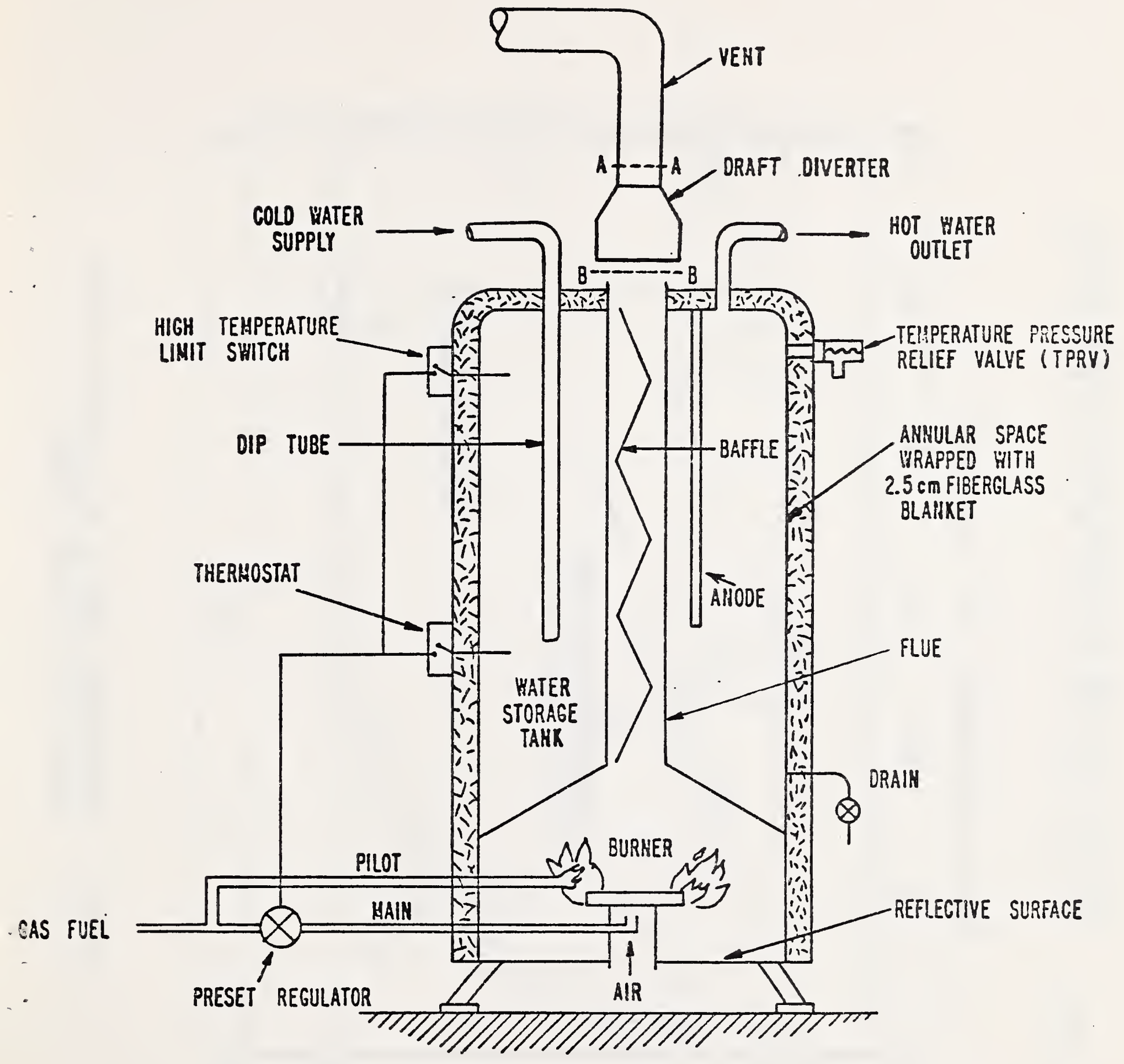

FIGURE 1. SCHEMATIC OF A TYPICAL GAS-FIRED WATER HEATER 


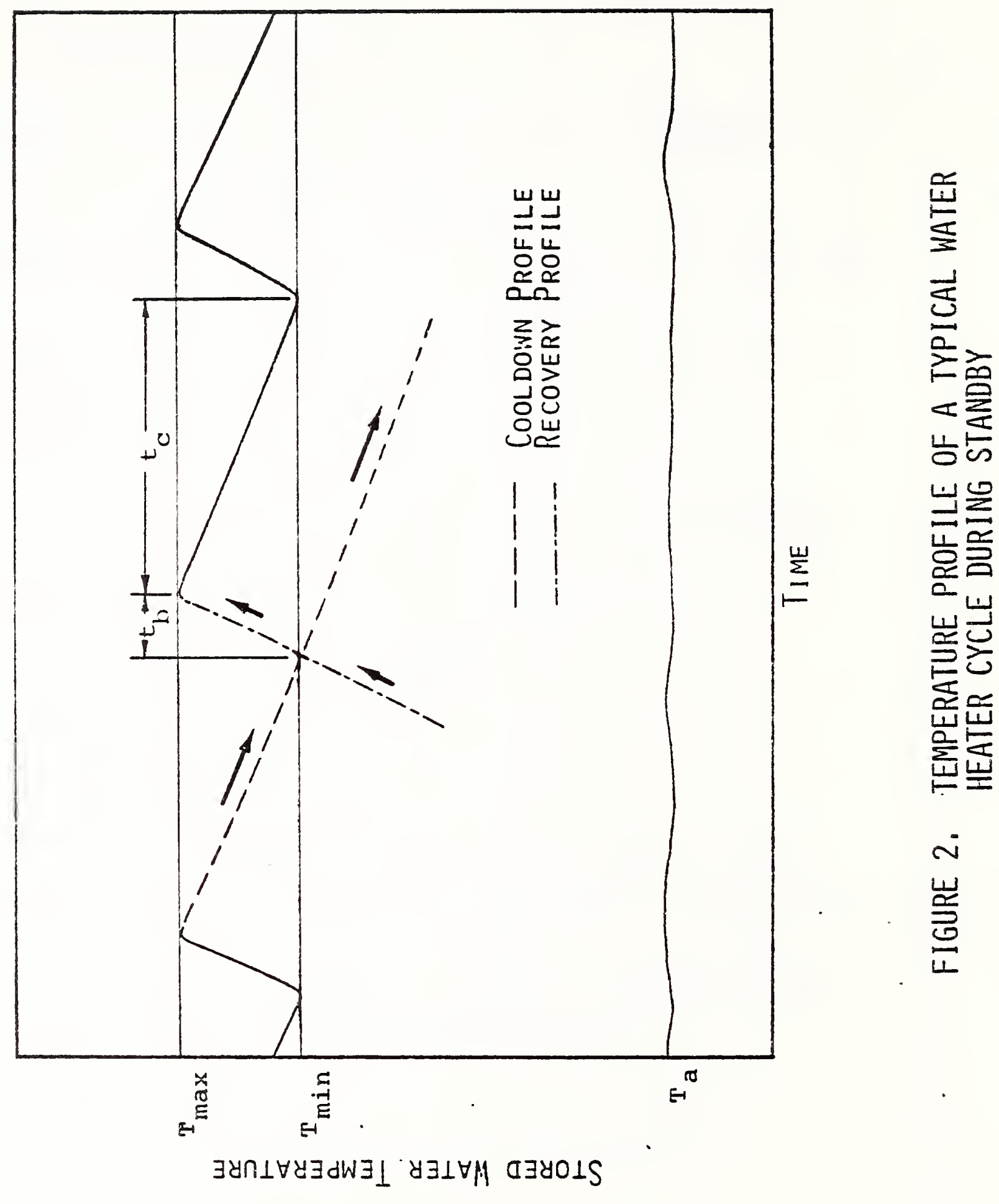




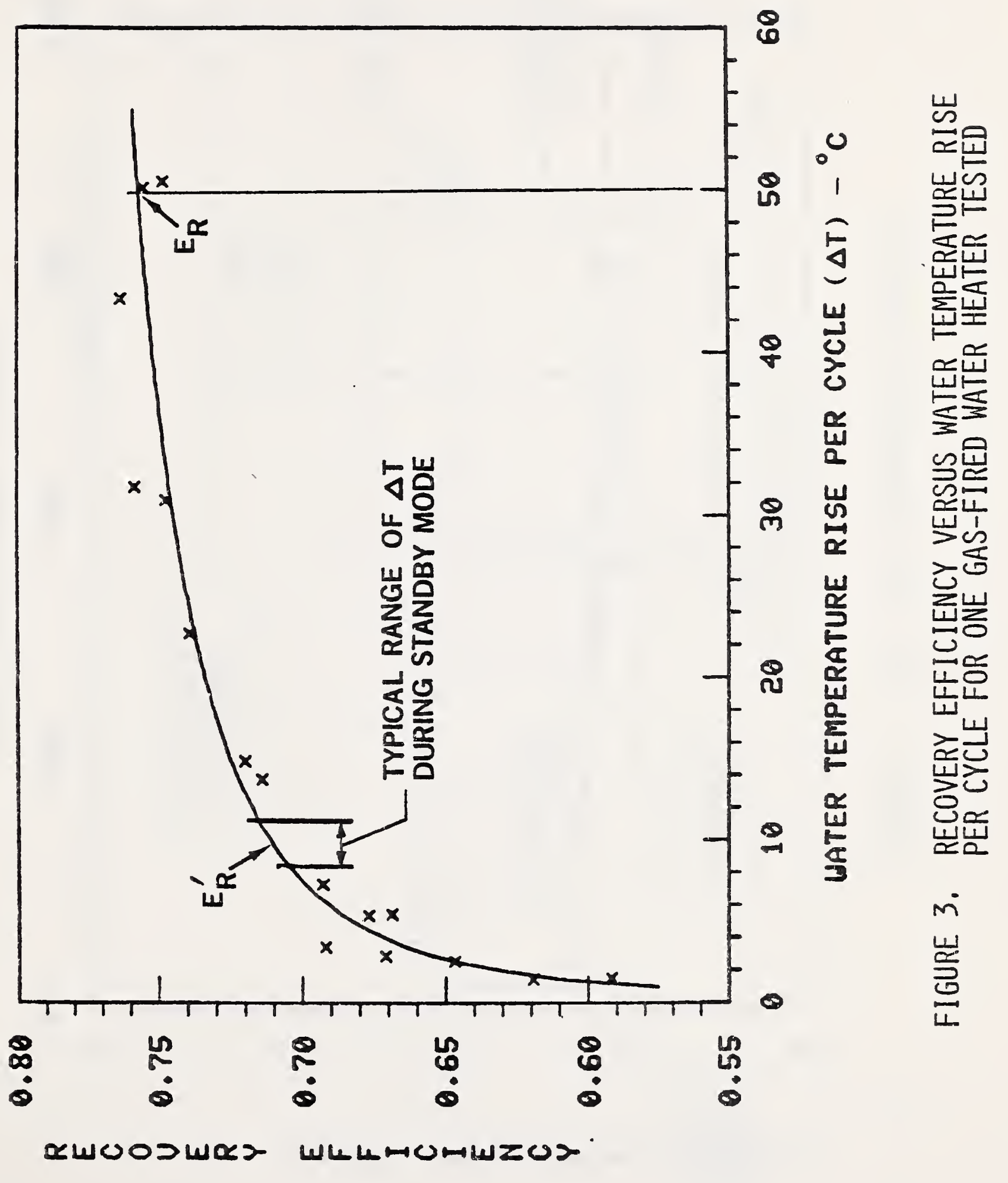




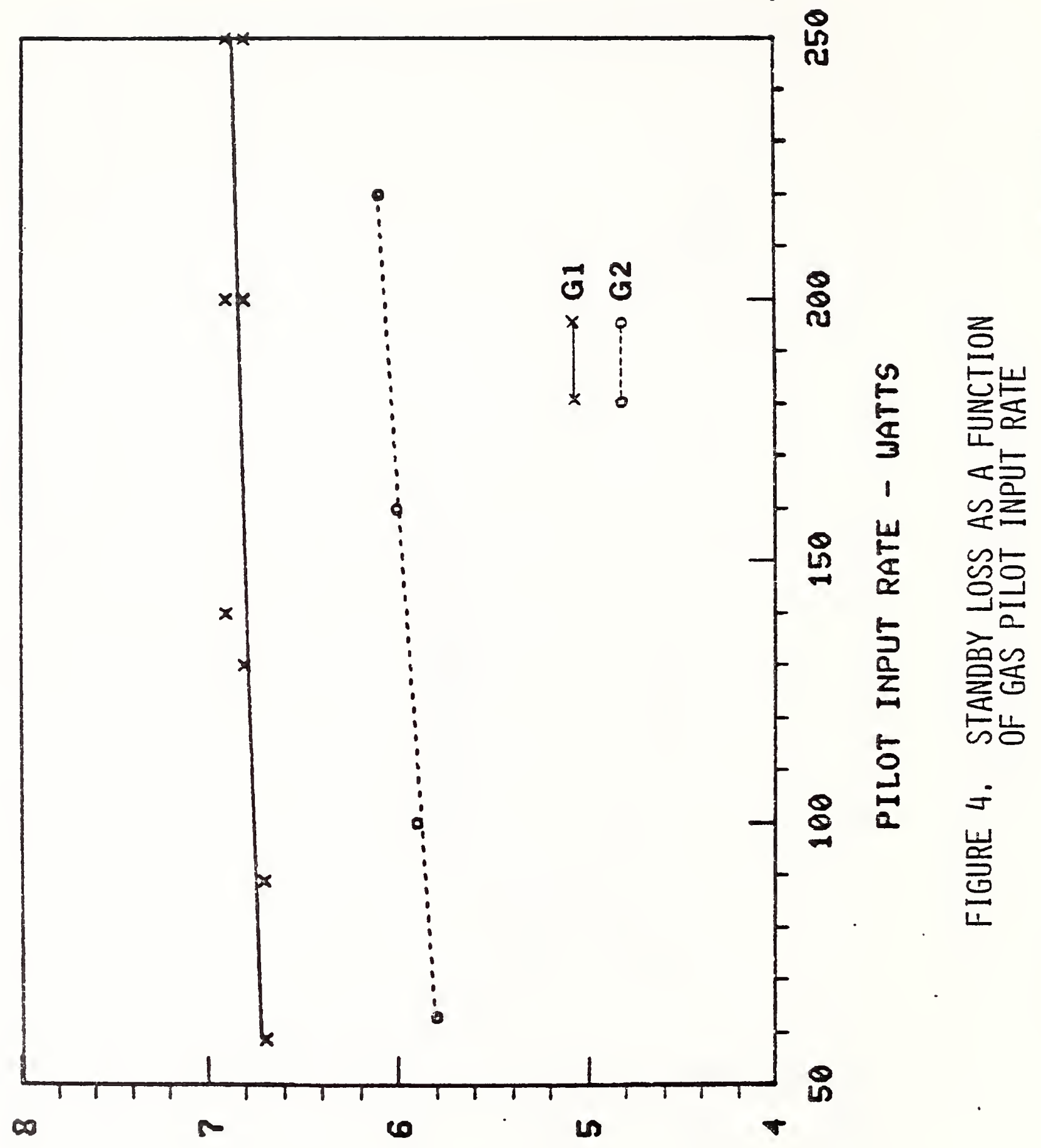

I0Dans entazons mone 


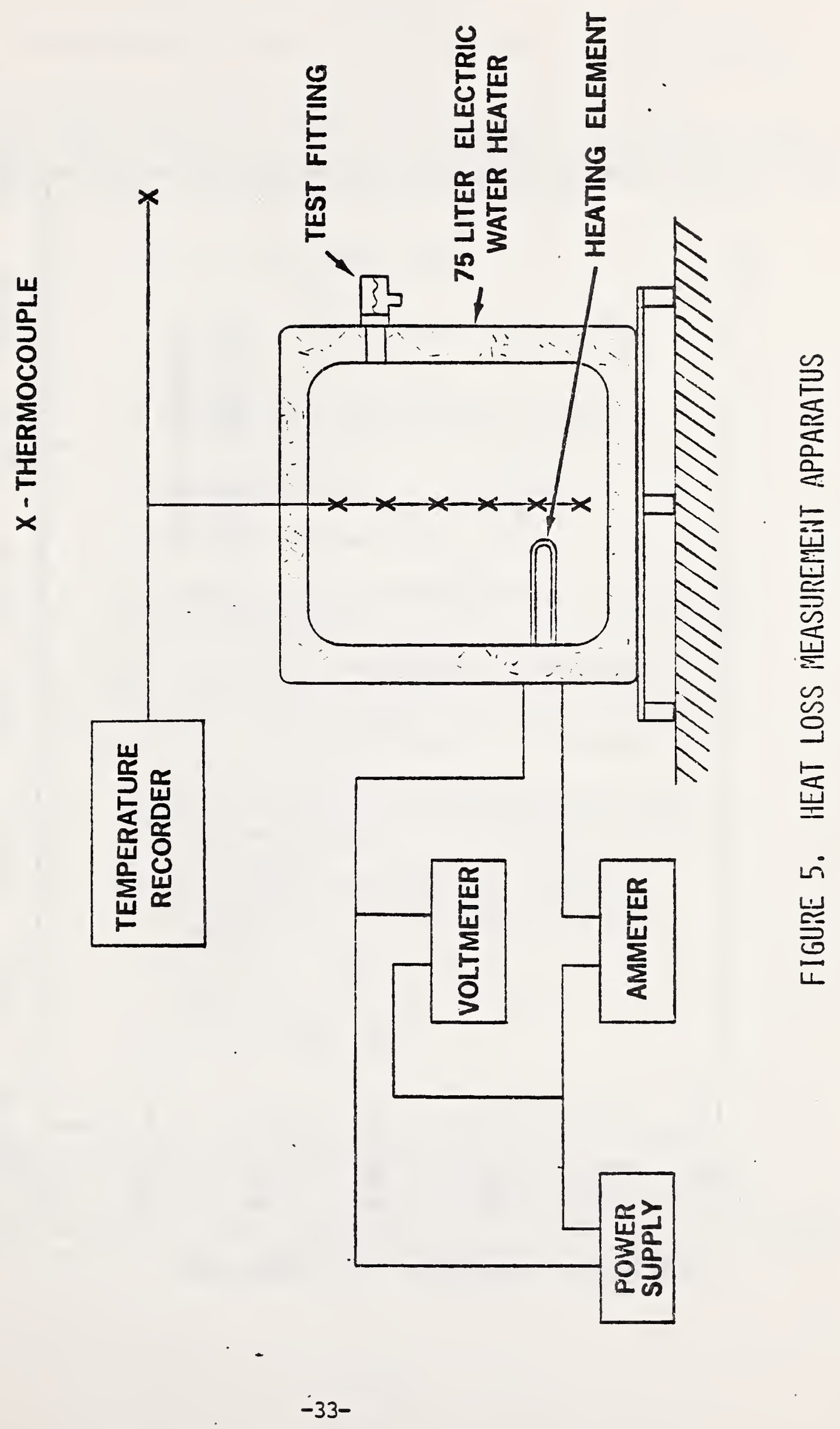




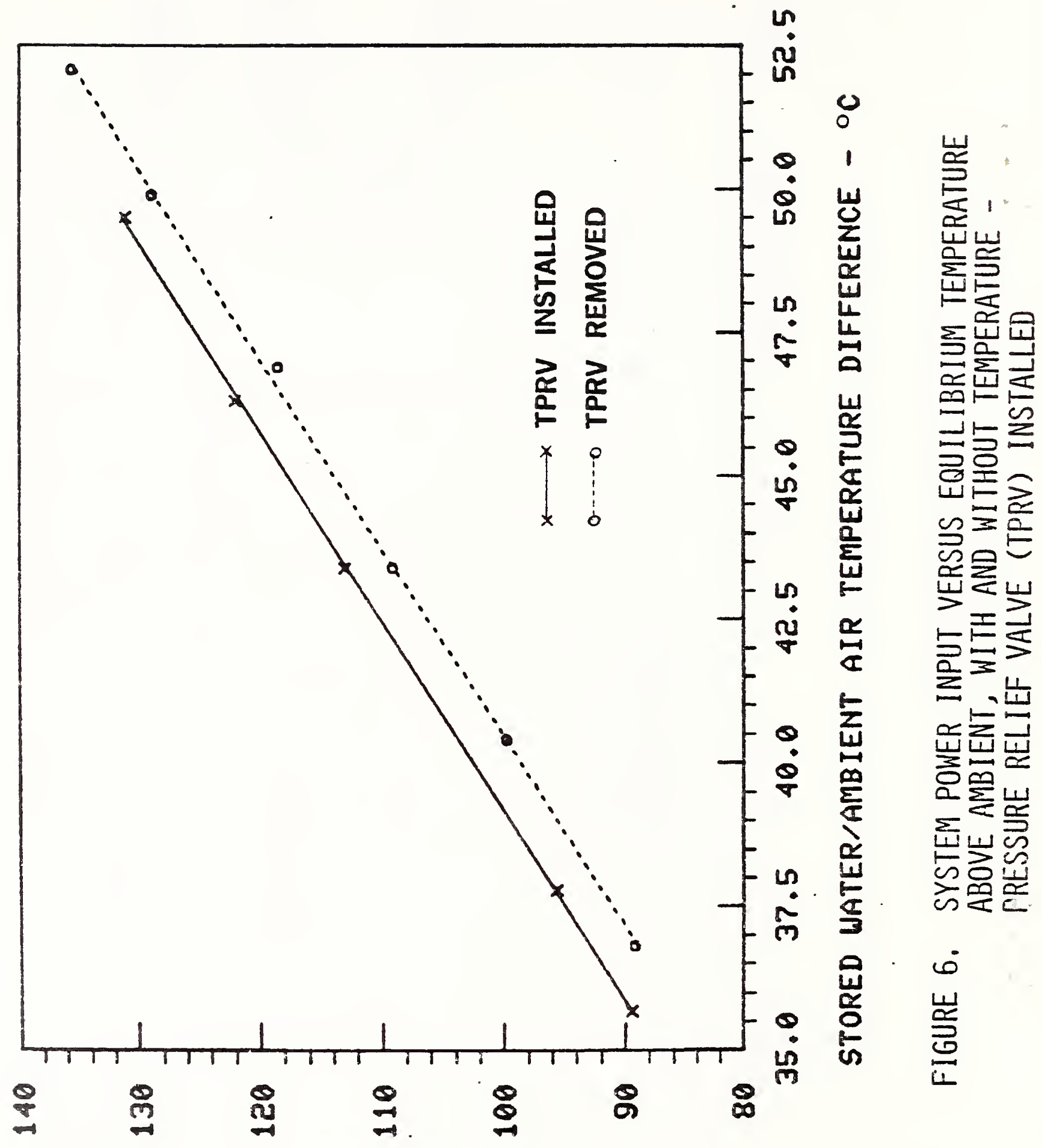

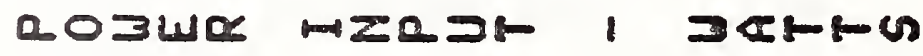


Determination of Standby Loss From Cool-Down and Recovery Tests

A typical water heater cycle, Figure 2, consists of two periods -- the period in which the burner is on $\left(t_{b}\right)$ and the period in which the volume of stored water cools from $T_{\text {max }}$ to $T_{\min }\left(t_{f}\right)$. From an energy balance on the

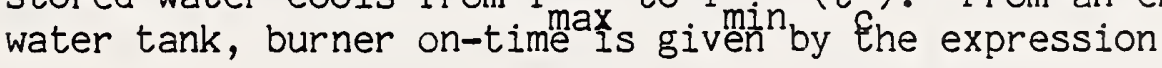

$$
t_{b}=\frac{V \rho C_{p}\left(T_{\max }-T_{\text {min }}\right)}{E_{r}^{\prime} q}
$$

where

$$
\begin{aligned}
& \begin{aligned}
& t_{b}= \text { duration of burner heating period in, } \\
& \text { standby mode }(h),
\end{aligned} \\
& \mathrm{V}=\text { tank volume }(\mathrm{L}) \text {, } \\
& \rho=\text { density of water }(\mathrm{kg} / \mathrm{L}) \text {, } \\
& \begin{aligned}
C_{p}= & \text { specific heat of water--taken to be } 4180 \mathrm{~J} / \mathrm{kg}^{\circ} \mathrm{C} \\
& (1.0 \mathrm{Btu} / \mathrm{lbm} \mathrm{F}),
\end{aligned} \\
& \mathrm{T}_{\max }=\begin{array}{l}
\text { stored water temperature at thermostat } \\
\text { cut-off }\left({ }^{\circ} \mathrm{C}\right) \text {, }
\end{array} \\
& \mathrm{T}_{\min }=\begin{array}{l}
\text { stored water temperature at thermostat } \\
\text { cut-on }(\mathrm{C}) \text {, }
\end{array} \\
& q=\text { energy input rate to main burner or heating } \\
& \text { element ( } k W) \text {, and } \\
& E_{r}^{\prime}=\text { cyclic recovery efficiency -- recovery } \\
& \text { efficiency for a water temperature rise } \\
& \text { from } T_{\min } \text { to } T_{\max } \\
& =\frac{V \rho C_{p}\left(T_{\text {max }}-T_{\text {min }}\right)}{Q_{r}}
\end{aligned}
$$

The recovery efficiency used in Equation Al is a measure of the efficiency at which energy is transferred to the stored water for a temperature rise from $\mathrm{T}_{\text {min }}$ to $\mathrm{T}_{\text {max }}$ (typically about $10^{\circ} \mathrm{C}$ ). This efficiency is termed the "cyclic recovery maxiciency" and is designated by the symbol $E_{r}$. The cyclic recovery efficiency is dependent upon the water 
temperature rise per cycle (temperauture differential) and water heater characteristics. This dependency is shown in Figure 3 for one gas-fired water heater tested.

The main burner is off during the period, $t$, when the stored water cools from $T_{\max }$ to $\mathrm{T}_{\text {min. }}$. From a single lumped capacity analysis for water heaters without pilots, water temperature during cool-down may be expressed as

$$
T=\left(T_{i}-T_{a}\right) \cdot \exp (-t / \tau)+T_{a}
$$

where

$$
\begin{aligned}
& T=\text { stored water temperature at time } t\left({ }^{\circ} \mathrm{C}\right), \\
& T_{i}=\text { stored water temperature at start of test }\left({ }^{\circ} \mathrm{C}\right), \\
& T_{a}=\text { average ambient air temperature during test }\left({ }^{\circ} \mathrm{C}\right), \\
& t=\text { time from start of test }(h) \text {, and } \\
& \tau=\text { water heater cool-down time constant }(h) .
\end{aligned}
$$

The rate of cool-down, represented by the inverse of the constant $\tau$, is a function of ( 1 ) the overall heat iransfer coefficient between the stored water and ambient, (2) heat transfer surface area, (3) tank volume, and (4) properties of the stored fluid. As such, the water heater time constant is a design-dependent water heater parameter which may be changed through water heater modifications such as the use of improved insulation, flue dampers, etc.

The cool-down rate of a given water heater may be determined by a simple test, termed a cool-down test. In this test, stored hot water at temperature $T_{j}$ is allowed to cool without the addition of heat by burner or pilot. The temperature difference between the stored water and ambient air, $T-T$, is recorded throughout the test. The time constant may then be evaluated from the relation

$$
\tau=t / \ln \left[\frac{T_{i}-T_{a}}{T-T_{a}}\right]
$$

which is the slope of the line obtained from a graph of $t$ versus $\ln \left[\frac{T_{i}-T_{a}}{T-T_{a}}\right]$.

Knowing the time constant for a particular water heater design, the time required for water to cool from a specified maximum temperature, $\mathrm{T}_{\max }$, to a minimum temperature, $\mathrm{T}_{\text {min }}$, is given as 


$$
t_{c}=\tau \cdot \ln \left[\frac{T_{\max }-T_{a}}{T_{\min }-T_{a}}\right] \text {. }
$$

The sum of $t_{b}$ and $t_{c}$, given by Equations $A I$ and $A 3$, is approximately equal to the duration of one complete cycle of a water heater. An expression for standby loss in terms of these parameters may now be derived. The standby loss of a gas- or oil-fired water heater is defined as

$$
S=\frac{Q_{S}+\frac{V \rho C_{p}\left(T_{i}-I_{f}\right)}{E_{r}}}{t V \rho C_{p}\left(T_{W}-T_{a}\right)} \times 100
$$

where

$$
\begin{aligned}
& S=\text { water heater standby } \operatorname{loss}(\% / h), \\
& Q_{S}=\text { total input energy consumed during the standby loss test }(\mathrm{J}), \\
& E_{r}=\begin{array}{l}
\text { standard recovery efficiency (for a } 50{ }^{\circ} \mathrm{C} \text { temperature rise), } \\
\text { (cimensionless), }
\end{array} \\
& t=\text { duration of standby test }(\mathrm{h}), \\
& \mathrm{T}_{i}=\text { stored water temperature at start of test }\left({ }^{\circ} \mathrm{C}\right), \\
& T_{f}=\text { stored water temperature at end of test }\left({ }^{\circ} \mathrm{C}\right) \text {, and } \\
& T_{W}=\text { average stored water temperature during test }\left({ }^{\circ} \mathrm{C}\right. \text { ) } \\
& T_{\text {max }}+T_{\text {min }} \\
& 2
\end{aligned}
$$

Considering a typical water heater cycle beginning and ending at $\mathrm{T}$ the second term in the numerator of Equation A4 vanishes. For one cycle $e^{\prime}$ (without pilot), the energy term $Q_{S}$ may be expressed as:

$$
Q_{S}=\frac{V \rho C_{p}\left(T_{\max }-T_{\text {min }}\right)}{E_{r}^{\prime}} \text {. }
$$

Making these substitutions and noting that the time for one complete cycle is simply the sum of the cool-down time and burner time, Equation A4 can be rewritten as

$$
S=\frac{T_{\max }-T_{\min }}{\left(t_{c}+t_{b}\right)\left(T_{W}-T_{a}\right) E_{r}^{\prime}} \times 100
$$


Through the use of Equation A6, water heater standby loss may be determined based on the water heater cool-down time copstant and cyclic recovery efficiency. Cyclic recovery efficiency, $E_{r}$, is obtained from recovery tests in which the temperature rise is approximately equal to that which occurs in a normal water heater cycle during standby, that is, $T$ minus T Equation $A 6$ is valid for water heaters without pilots. Imaxas used ininetermining standby loss with simulated intermittent ignition and flue dampers. 


\section{Appendix B}

Effect of Thermostat Reduction on Water Heating Energy Requirements

To consider the effect of a thermostat setback on water heater energy consumption, it must be recognized that a water heater has two supply functions: an energy related function to supply hot water for personal use such as a shower, and a volume function to supply such appliances as the clothes washer and dishwasher. The latter have no control on the temperature of the water delivered and accept what comes through the hot water connection. The amount of water used by these appliances is controlled either by a timer or volume control. The amount of flow through the water heater for any temperature rise $\Delta \mathrm{I}_{I}^{\prime}$,
can be expressed as:

where

$$
U^{\prime}=\left[\phi+\frac{\Delta T_{I}}{\Delta T_{I}^{\prime}}(I-\phi)\right] U
$$

$\mathrm{U}=$ daily hot water usage rate before thermostat setback -- base flow (L/day),

$U^{\prime}=$ daily hot water usage rate after thermostat setback (L/day)

$\phi=$ fraction of base flow water, $U$, going to clothes washer and dishwasher (dimensionless).

$\Delta T_{1}=$ difference between water heater inlet and outlet temperatures before thernostat setback $\left({ }^{C}\right)$, and

$\Delta T_{1}^{\prime}=$ difference between water heater inlet and outlet temperatures after thermostat setback $\left({ }^{\circ} \mathrm{C}\right)$.

The breakdown of water consumption between fixed-volume and fixedtemperature demands is illustrated in Figure BI for a base hot water usage rate, $U$, of $243 \mathrm{~L} /$ day, base temperature use, $\Delta \mathrm{T}_{1}$, of $90^{\circ} \mathrm{F}$, and a fixed flow fraction, $\phi$ of 0.3 . Corresponding reductions in thermal energy delivered to fixed-volume demands are shown in Figure B2. (The energy delivered to fixed-temperature demands is constant). Recalling that thermal energy is converted at approximately the water heater recovery efficiency, it can be seen that for a $10^{\circ} \mathrm{C}$ thermostat setback, these volume-related energy savings account for about a 4 percent savings in total energy consumption (Table 1), or roughly $1 / 3$ of the total energy savings obtained through therinostat setback (Table 3). 


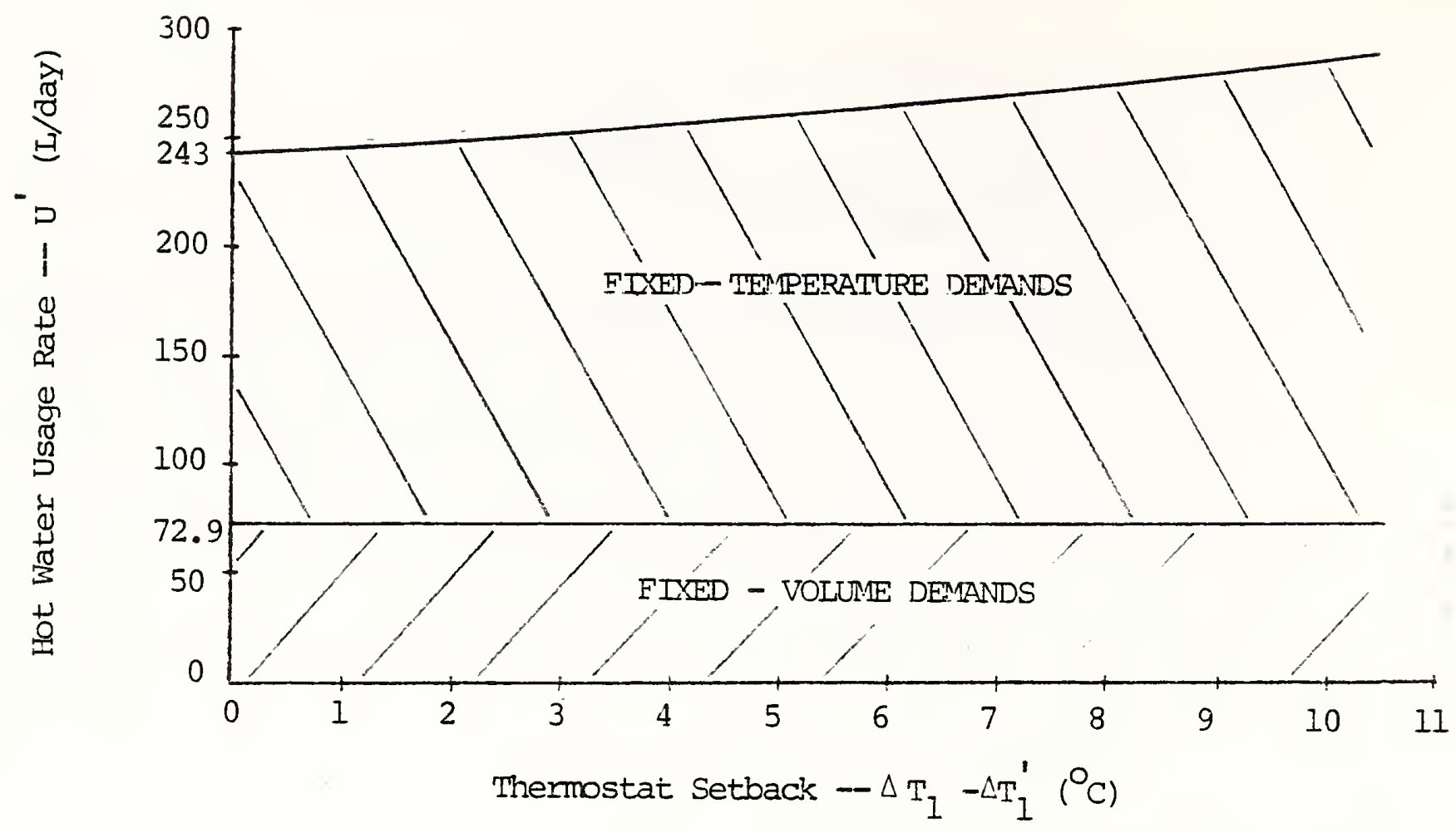

FIGURE BI - HOT WATER USAGE RATE VERSUS THERMOSTAT SETBACK
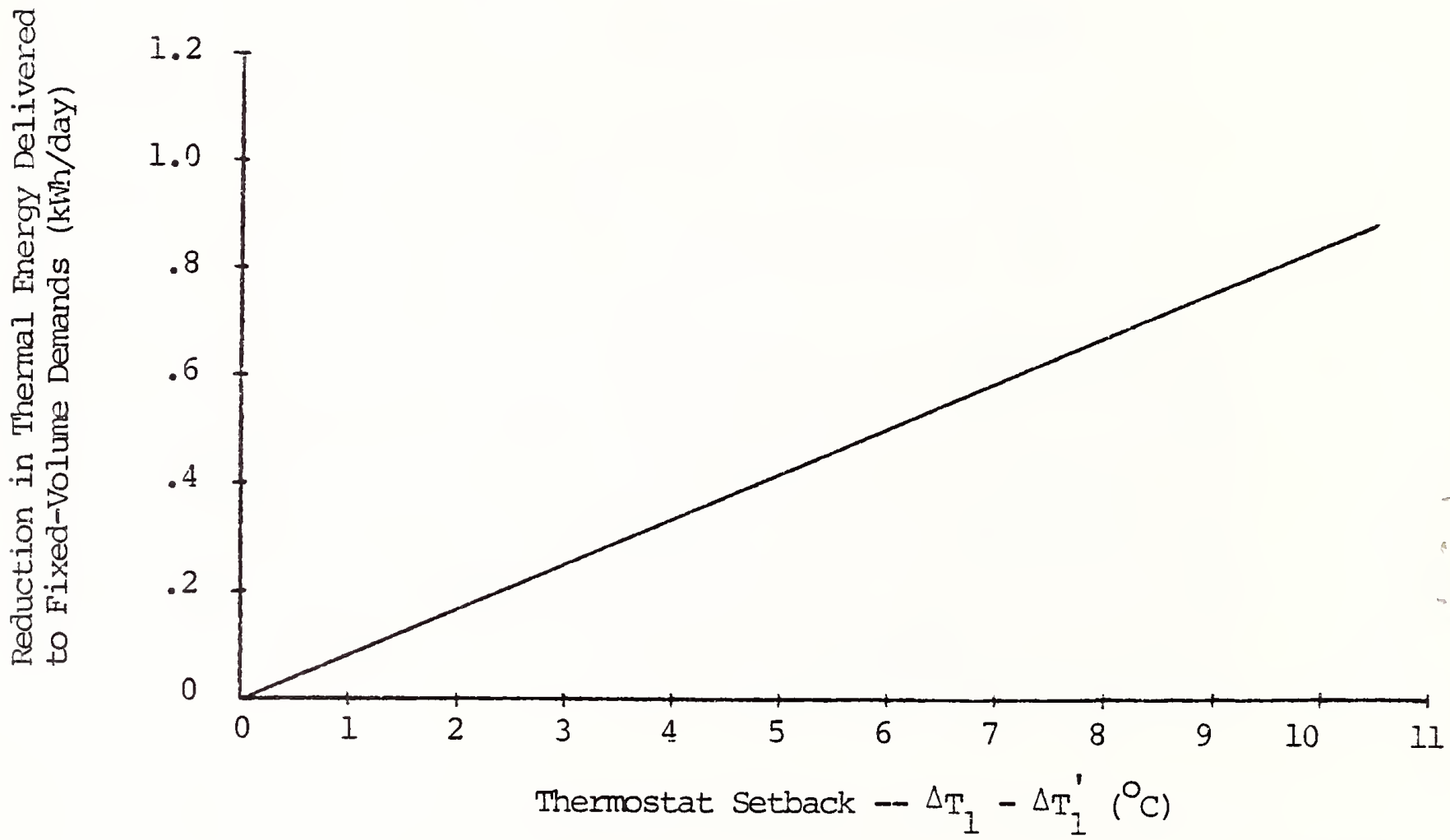

FIGURE B2 - REDUCTION IN THERMAL ENERGY DELIVERED TO FIXED-VOLUME DEMANDS VERSUS THERMOSTAT SETBACK 
The daily energy required to supply U' L/day of hot water is given as:

$$
E=\frac{\rho C_{p} \Delta T_{1}^{\prime} U^{\prime}}{E_{r}}+\left[24-\frac{\rho C_{p} \Delta T_{1}^{\prime} U^{\prime}}{q E_{r}}\right] \frac{\rho C_{p} V S \Delta T_{2}^{\prime}}{100}
$$

where the first term on the right of this equation is the amount of energy required per day to heat the required amount of water $U^{\prime}$, and the second term represents the amount of energy required per day to make up the thermal losses from the stored water.

Specifically:

$E$ = total input energy consumed per day by water heater (energy content of unburned fuel and electric input), (J/day),

$\rho=$ density of water -- taken to be $0.989 \mathrm{~kg} / \mathrm{L}$,

$C_{p}=$ specific heat of water - taken to be $4180 \mathrm{~J} / \mathrm{kg}^{\circ} \mathrm{C}$,

$E_{r^{\prime}}=$ standard recovery efficiency (from Equation 1 in text)

$q=$ energy input rate to main burner or heating element $(\mathrm{kW})$,

$V=$ tank volume (L),

$S=$ water heater standby loss (from Equation 2 or 3 in text), and

$\Delta \mathrm{T}_{2}^{\prime}=$ difference between stored water temperature and ambient air temperature after thernostat setback $\left({ }^{\mathrm{C}}\right)$.

Equation $\mathrm{Bl}$ can be substituted into Equation $\mathrm{B} 2$ with the following result,

$$
E=\left[A-B\left(\Delta T_{1}^{\prime}-\Delta T_{a}\right)\right]\left[\phi \Delta T_{I}^{\prime}+(1-\phi) \Delta T_{1}\right]+C\left(\Delta T_{I}^{\prime}-\Delta T_{a}\right)
$$

where

$$
\begin{aligned}
& A=\frac{\rho C_{p} U}{E_{r}} \\
& B=\frac{\left(\rho C_{p}\right)^{2} U V S}{100 q E_{r}}
\end{aligned}
$$

$C=0.24 \rho C_{p} V S$, and

$\Delta \mathrm{T}_{a}=$ difference between ambient air temperature and inlet water temperature $\left({ }^{\circ} \mathrm{C}\right)$.

$$
=\Delta T_{1}^{\prime}-\Delta T_{2}^{\prime}
$$


Equation B3 lends itself to calculating the daily energy requirements for any condition of inlet water temperature, ambient air temperature, temperature rise through the water heater, water heater characteristics, and volume flow fraction.

Through a survey it has been determined by the Product Systems Analysis Division at NBS that for a temperature rise $\Delta \mathrm{T}_{1}=50^{\circ} \mathrm{C}$, and a fixed ambient to inlet water temperature difference, $\Delta \mathrm{T}_{1}$, of $0^{\circ} \mathrm{C}$, the average daily hot water use, $\mathrm{U}$, is equal to 243 liters per day or 1700 liters per week. In a separate survey by the same group it was determined that the fixed volume flow fraction, $\phi$, of the base flow $U$ was on the average equal to 0.3 .

For actual water heater operation, the cold water inlet temperature has been geographically, demographically and seasonally averaged to a vaIue of $13^{\circ} \mathrm{C}$. When combined with a $50^{\circ} \mathrm{C}$ temperature rise, an average tank water temperature, of $63^{\circ} \mathrm{C}$ is obtained. This temperature corresponds to the average thermostat setting of electric, gas-, and oil-fired water heaters as normally installed in most households. 


\begin{tabular}{|c|c|c|c|}
\hline $\begin{array}{l}\text { U.S. DEPT. OF COMM. } \\
\text { BIBLIOGRAPHIC DATA } \\
\text { SHEET }\end{array}$ & $\begin{array}{l}\text { 1. PUBLICATION OR REPORT NO. } \\
\text { NBSIR79-1783 }\end{array}$ & 2. Gov't Accession No. & 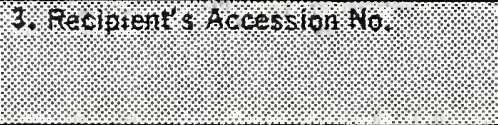 \\
\hline \multicolumn{3}{|l|}{ 4. TITLE AND SUBTITLE } & 5. Publication Date \\
\hline \multirow{2}{*}{\multicolumn{3}{|c|}{$\begin{array}{l}\text { Evaluation of Energy Conserving Modifications for } \\
\text { Water Heaters }\end{array}$}} & \\
\hline & & & 6. Performing Organization Code \\
\hline \multicolumn{3}{|l|}{ 7. AUTHOR(S) } & 8. Performing O:gan. Report No. \\
\hline \multicolumn{3}{|c|}{ Robert I. Palla, Jr. } & \\
\hline \multicolumn{3}{|c|}{ 9. PERFORMING ORGANIZATION NAME AND ADDRESS } & 10. Project/Task/Work Únit No. \\
\hline \multicolumn{3}{|c|}{$\begin{array}{l}\text { NATIONAL BUREAU OF STANDARDS } \\
\text { DEPARTMENT OF COMMERCE } \\
\text { WASHINGTON, DC } 20234\end{array}$} & 11. Contract/Grant No. \\
\hline \multirow{3}{*}{\multicolumn{3}{|c|}{ 12. SPONSORING ORGANIZATION NAME AND COMPLETE ADDRESS (Street, City, state, ZIP) }} & 13. Type of Report \& Period Covered \\
\hline & & & \\
\hline & & & 14. Sponsoring Agency Code \\
\hline
\end{tabular}

15. SUPPLEMENTARY NOTES

$\square$ Document describes a computer program; SF-185, FIPS Software Summary, is attached.

16. ABSTRACT (A 200-word or less factual summary of most significant information. If document includes a significant bibliography or literature survey, mention it here.)

The effects of various energy-conserving modifications on water heating energy consumption were evaluated based on laboratory tests. Nine storage-type residential water heaters, representative of standard and "energy-saving" electric, gas, and oil fueled models currently on the market, were obtained for testing. Federallypromulgated water heater test procedures were used to measure the energy consumption of each unit before and after modifications. Energy-conserving modifications and corresponding projected reductions in energy consumption included: reduced thermostat settings $\left(10^{\circ} \mathrm{C}\right), 12$ percent savings for standard electric, gas, and oil fueled water heaters (where appliance performance does not degrade below an acceptable level, and water heater capacity is still sufficient to meet hot water needs); and improved insulation, 9 percent savings for all water heater fuel types. Also considered for gas-fired units were reduced pilot input rate from $220 \mathrm{~W}$ to $60 \mathrm{~W}$ $(750 \mathrm{Btu} / \mathrm{h}$ to $200 \mathrm{Btu} / \mathrm{h})$, less than 2 percent savings; use of thermal danpers, 3 percent savings; use of intermittent ignition, 5 percent savings; and use of intermittent ignition and mechanical flue dampers, 11 to 16 percent savings. Modifications to energy-saving models resulted in somewhat smaller reductions. Multiple modifications were found to offer energy savings slightly less than the sum of the individual savings.

17. KEY WORDS (six to twelve entries; alphabetical order; capitalize only the first letter of the first key word unless a proper nama; separated by semicolons)

Energy conservation; energy consumption; heat loss; insulation; modifications; gas pilot; recovery efficiency; residential; standby loss; test procedures; water heaters

\begin{tabular}{|c|c|c|}
\hline 18. AVAILABILITY X Unlimited & $\begin{array}{l}\text { 19. SECURITY CLASS } \\
\text { (THIS REPORT) }\end{array}$ & $\begin{array}{l}\text { 21. NO. OF } \\
\text { PRINTED PAGES }\end{array}$ \\
\hline$\square$ For Official Distribution. Do llot Release to NTIS & UNCLASSIFIED & 50 \\
\hline $\begin{array}{l}\text { Order From Sup. of Doc., U.S. Government Printing Office, Wasinington, DC } \\
20402 \text {, SD Stock No. SNO03-003- }\end{array}$ & $\begin{array}{l}\text { 20. SECURITY CLASS } \\
\text { (THIS PAGE) }\end{array}$ & 22. Price \\
\hline $\begin{array}{l}\text { X Order From National Technical Information Service (NTIS), Springfield, } \\
\text { VA. } 22161\end{array}$ & UNCLASSIFIED & $\$ 4.50$ \\
\hline
\end{tabular}



